\title{
علم مقارنة الأديان بين سؤالي المفهوم والموضوعية: دراسة تحليليّة مقارنة
}

\section{عبد الرّزاق عبد الله حاش}

$$
\begin{aligned}
& \text { الملخص } \\
& \text { تتناول هذه الدراسة بمنهج تحليلي مقارن، مفهوم علم مقارنة الأديان وإمكانيّة تطويره بصورة موضوعية. وتضمن }
\end{aligned}
$$

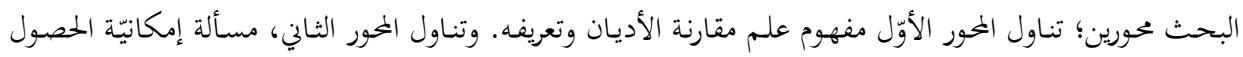

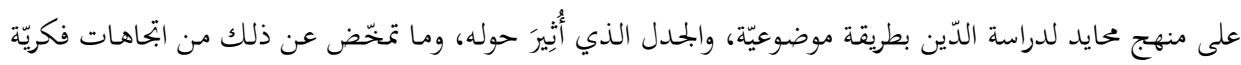

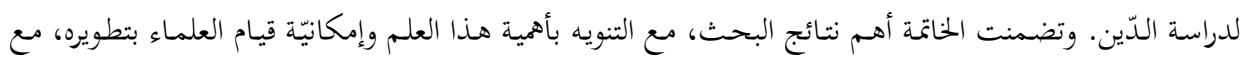

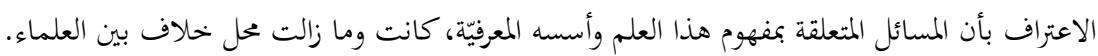

$$
\begin{aligned}
& \text { الكلمات المفتاحيّة: علم مقارنة الأديان، الموضوعيّة، إمكانيّة الحصول عليه، مقاربات العلماء. }
\end{aligned}
$$

\section{Comparative Religion between Concept and Objectivity: Analytical Comparative Study}

\begin{abstract}
This study uses analytical and comparative methods to analyze the concept and objectivity of the discipline of comparative religion. The study is divided into two themes. The first one deals with the definition of the discipline of comparative religion. The second deals with issues related to the objectivity of this discipline. The study concludes with acknowledging the importance of comparative religion, and the need to develop its content and methodology. However, scholars in this field of study have and will continue to have different understandings of the concept of comparative religion.

Keywords: Discipline of comparative religion, objectivity, methodology, approaches.

• دكتوراه في أصـول الـدين ومقارنـة الأديـان، أستاذ مسـاعد بكليـة العلوم، الجامعـة الإسـلامية العالميـة بماليزيـا، البريـد hashi@iium.edu.my الإلكتروني

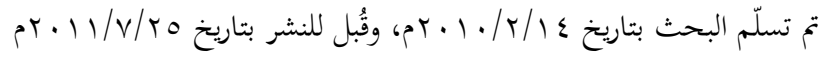




\section{مقدمة:}

يختص علم مقارنة الأديان بالوقوف على حقيقة المعتقدات الدينيّة، والتّعرّف على مـدى صحتها، وما تشابه منها، ومواطن الخـلاف بينها. إلا أن المسـائل المتعلقة بمفهوم

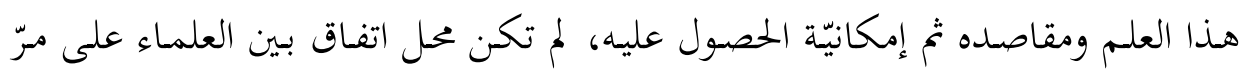

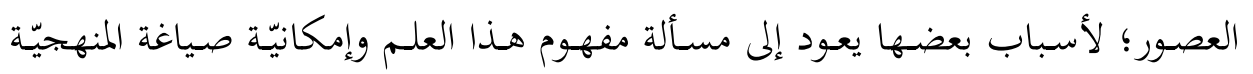

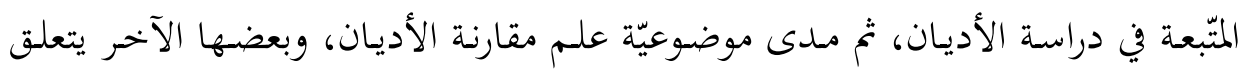
بتحديد الموضوع الذي يتَّصل به علم مقارنة الأديان وهو الدين ومفهومه. ومسن الأسئلة التي تثار هنا: هـل بإمكاننـا فهم الظّاهرة الدينيّة على نحو موضوعيّ

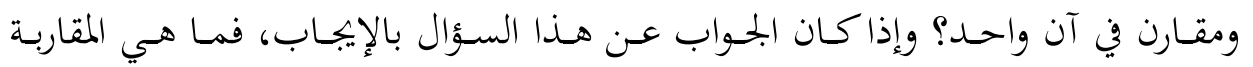

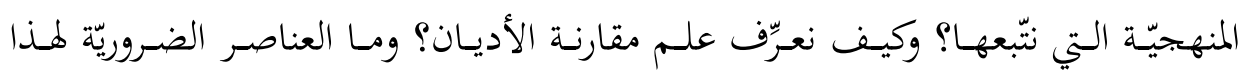

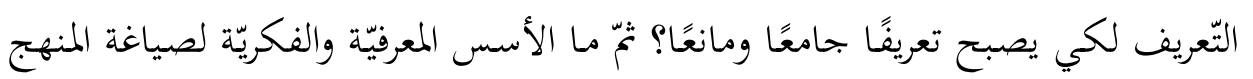

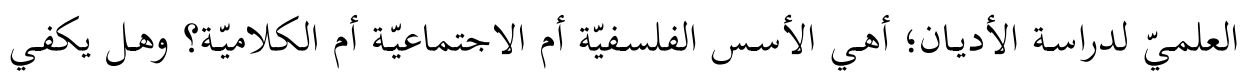

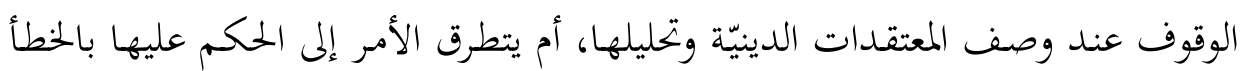

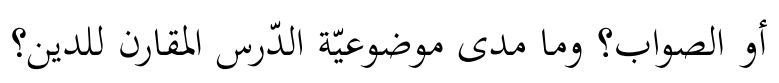
يهاف هذا البحتث إلى تناول إجابات العلماء عن هذه الأسئلة وغيرها، التي تثار من وقت لآخر حول مفهوم علم مقارنة الأديان وإمكانيّة بنائه بصورة موضوعية.

\section{أولاً: علم مقارنة الأديان وسؤال المفهوم}

مـن حيـث الأصـل اللغويّ،، تشـير قواميس اللغـة العربيّة إلى أن مـادة "قَـارَنَ مُعَارَنَةً

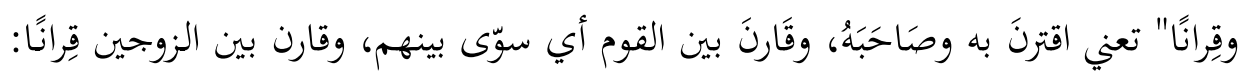

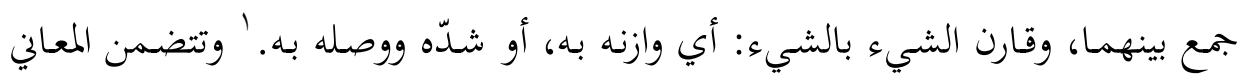

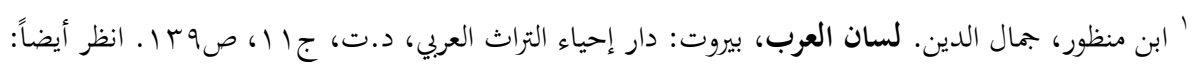

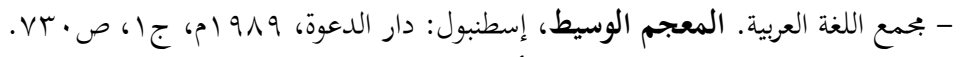

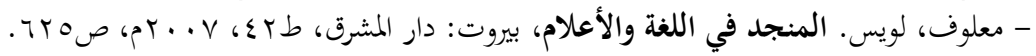


اللغوية لكلمة "المقارنة" هنا عدّة مفاهيم كالوصل، والجممع، والمصاحبة، والتسوية والربط، وهي مفاهيم تدل على الاقتران والمصاحبة والاشتراك. وفي اللغة الإبحليزية بنحد أنّ كلمة تعني الموازنة أو الفحص من أجل التعرّف على التشابه من عدمـه. بُ وعليه (compare)

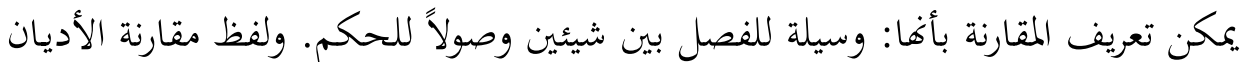
the (comparative religion) (comparative study of religion

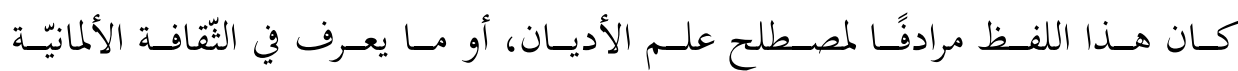
(religionswissenschaft)

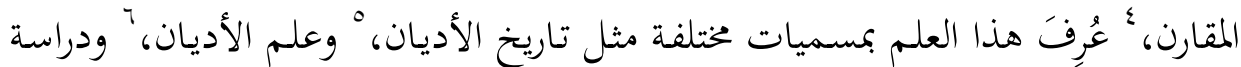

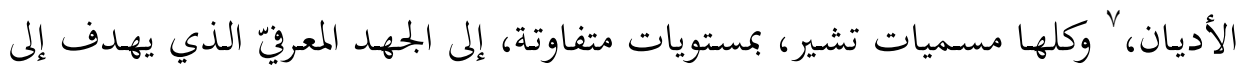

2 J. Milton Cowan (ed.), A dictionary of modern written Arabic, (London: Macdonald and Evans LTD, 1960), p.760

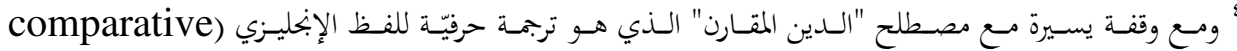
religion

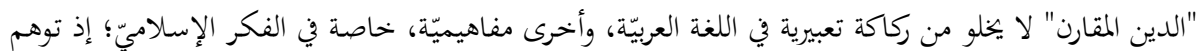

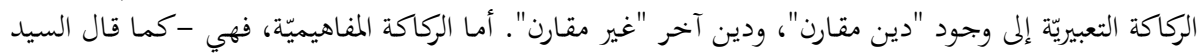

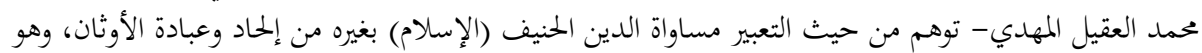

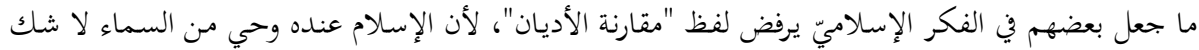

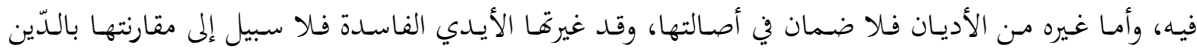

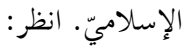

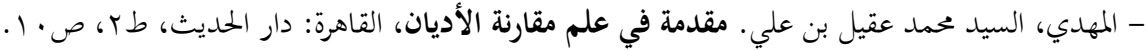

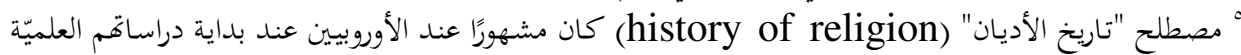

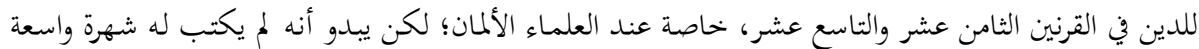

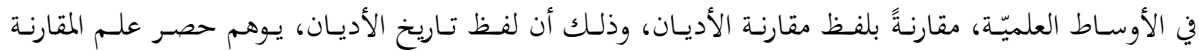

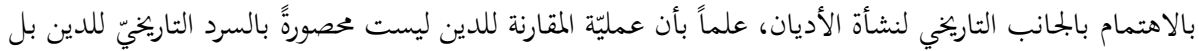

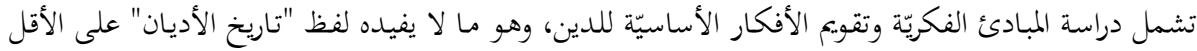

من حيث الدلالة اللفظيّة. “' لفظ علم الأديان (Science of religion)، مصطلح وظّّفه ماكس ميلر؛ عالم اللغويات الألمانيّ، في محاضرته

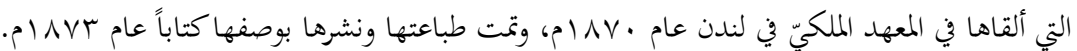

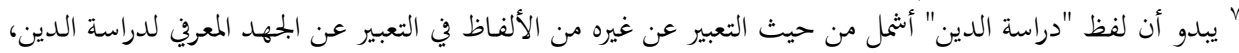

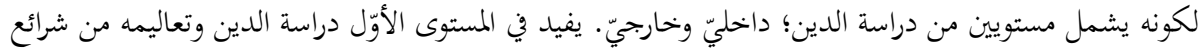


Mircea (اراسة الظاهرة الدينيّة بشكل مقارن. ومن الناحيّة التاريخيّة، يؤكد ميرسيا إليادا (Eliade

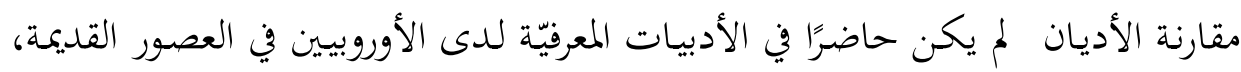
ولم يظهر مصطلح علم مقارنة الأديان في كتابات الباحثين الأوروبيين الذين درسوا الفكر الذروبين الدينيّ في العصور الوسطى، حتى فهاية القرن التاسع عشر الميلاديّ؛ إذ أطلقها لأوّل مرة

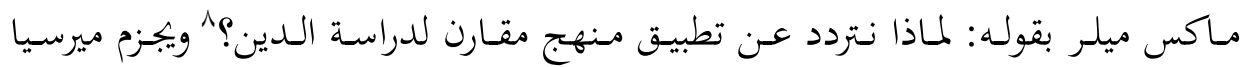

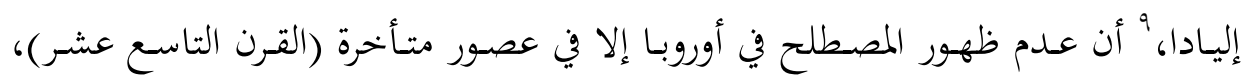

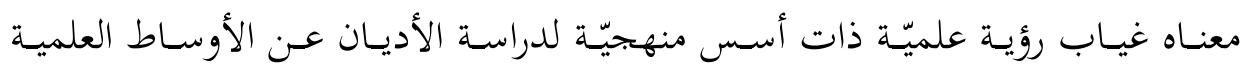
والمعرفية في أوروبا.

ومـن حيـث التعريـف العلميّ لــذا العلم في الغـرب، يشـير أريـك شـارب في مدونته تاريخ مقارنة الأديان، إلى أنه ومع أن علم الدّين المقارن كان حاضراً في الأدبيات المعرفيّة

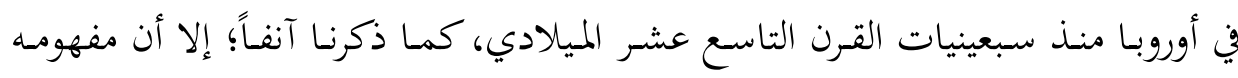

وعقائد من أجل تطبيقها خاصة عند المؤمنين جما، كما يفيد في المستوى الثاني دراسة الدين بشكل مقارن بغيره من الأديان وفق منهج علميّ ومعرقيّ معين.

8 Introduction of science of religion, London, 1873, p.15, cited in: Sharpe, Eric J. Comparative religion: A history, London: Duckworth, 1975, xii

${ }^{9}$ Eliade, Mircea. Comparative Religion in The Encyclopedia of Religion, New York: Macmillan, 1987, p.578.

وهذا الجزم هو ما يفيده كلام ماكس ميلر؛ عالم اللغويات الألمايّ، في محاضرته التي ألقاها في المعهد الملكيّ في

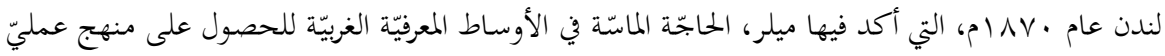

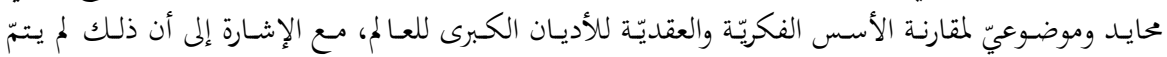

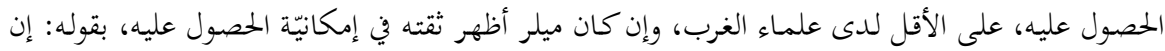

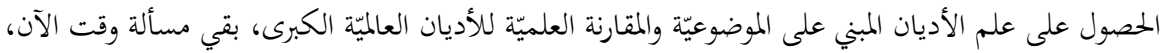

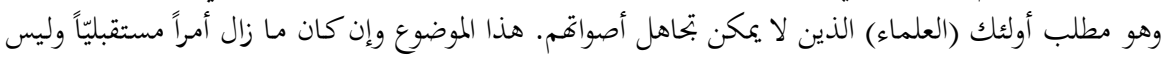

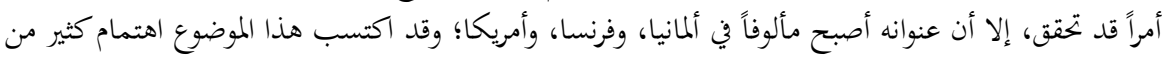

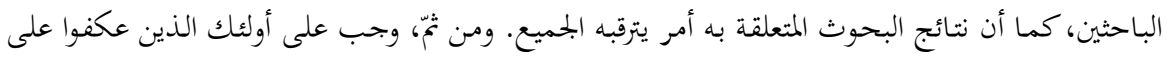

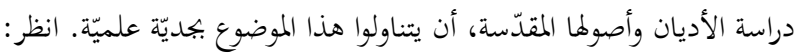

- Muller, Max. Introduction of Science of Religion, London: Longmans. 1873), p.34 
الاصطلاحيّ لم يَخظً بتعريف علميّ جامعٍ ومانع، إلا في بداية القرن العشرين الميلاديّ،

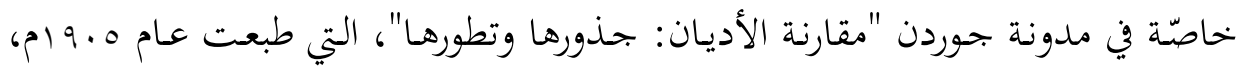
وفيها عرَّف جوردن علمَ مقارنة الأديان، بأنه: "الدرس العلميّ الذي يقارن بين أصول مدولي المعتقدات وأشكال الطقوس والعبادات لأديان العالم، لمعرفة أوجه التشابه والتباين بينهم، وتحديد القواسم المشتركة وعلاقة بعضها ببعض، ومعرفة مواطن القوة والضّعف فيما بينهم من خلال المقابلة والموازنة، كأجناس." ·'

وفي هذا التعريف تحديد لعنصرين مهمّين لهذا العلم، هما؛ مفهوم هذا العلم ووظيفته، يَتَتَنَّلُ الأوّل في دراسة أصول المعتقدات وأشكال الطقوس والعبادات لأديان العالم على لم

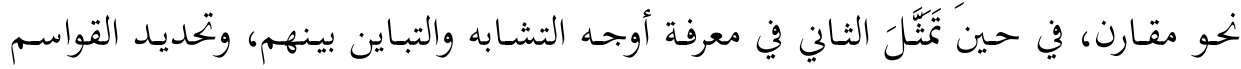
المشتركة وعلاقة بعضها ببعض، كأجناس. ولأنه تضمن هذين العنصرين، اكتسب هذا

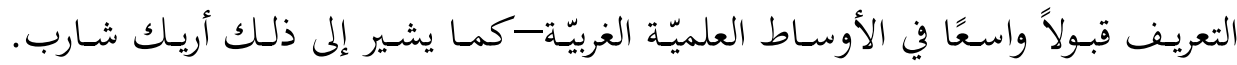
فقواميس الدّين المقارن في الغرب تدور في فلكه. وعلى سبيل المثال لا الحصر، بند تعريفاً مشابهاً للتّعريف الأول من حيث المضمون، في الموسوعة الإلكترونيّة ويكيبيديا، وإن اختلف عنه في التعبير، مفاده، أن مقارنة الأديان هي: "بحال دراسة الدين، الذي يقوم بتحليل أوجه التشابه والاختلاف بين الموضوعات،

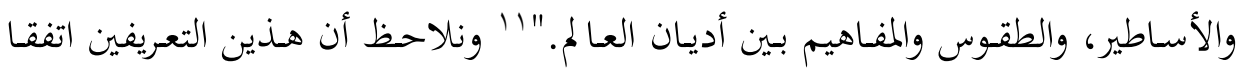
على أن موضـوع علـم مقارنـة الأديـان هـو المعتقــات الدينيّة، وأن وظيفتـه هي المقارنـة الموضـوعيّة للــدين، الـتي تتوقـف عنـــ وصـف المبـادئ والقـيم الدينيّـة وتحليلهـا، وتحليـل تواريخها، وتحديد مدى التشابه والتباين بينها.

10 Jordan, Louis Henry. Comparative religion: Its genesis and growth, Atlanta: Scholars Press, 1905, p.63, see also:

- Sharpe, Eric J. Comparative religion: A history, (London: Duckworth, 1975), xii.

${ }^{11}$ http://en.wikipedia.org/wiki/Comparative religion (22 February, 2010) 
ومع أن تعريف جوردن تضمَّن ذكر كون المعتقدات الدينية بجالاً للدّراسة، إلا أن

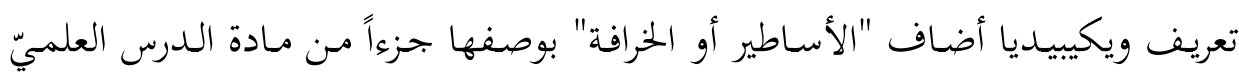

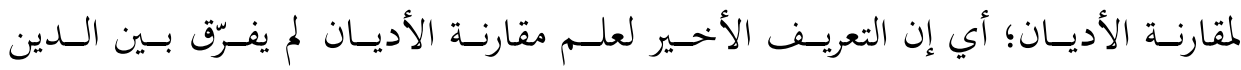

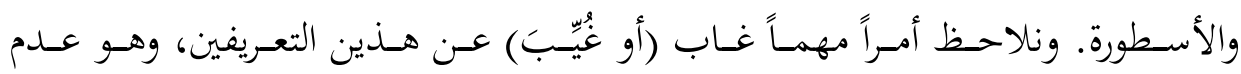
تضمنهما العنصر المعياريّ لهذا العلم (judgments)، الذي به تتميّز المعتقدات إلى حقّ وباطل؛ حقّ يجب الأخذ به، أو باطل لا قيمة له. ولم يصرّح كل من هذين التعريفين ما

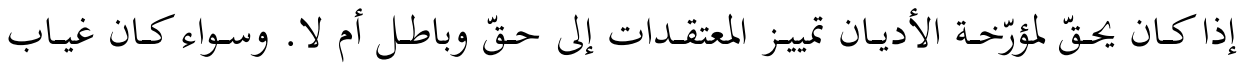
العنصر المعياريّ من تعريف مفهوم علم مقارنة الأديان عن قصدٍ، لكون الكاتب لا يؤمن بضرورة إدخاله، أم لكونه يؤمن بفقدان التعاليم الدينيّة للقيمة الذاتيّة (القدسيّة)، أو عن غير قصدٍ، فإن غيابه منه يجعل التعريف غير مستوفٍ لشروط قبوله بوصفه تعريفاً جامعاً

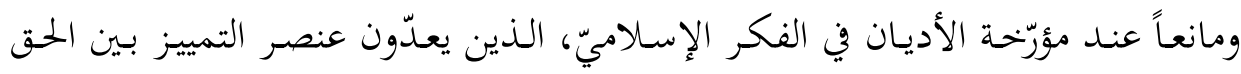
والباطل في الدين عنصرًا محوريَّا في هذا العلم، كما سنرى ذلك لاحقًا. أمـا مفهومـه الاصطلاحيّ عند مؤرّخة الأديان في الفكر الإسـلاميّ، فبإن هـا العلم

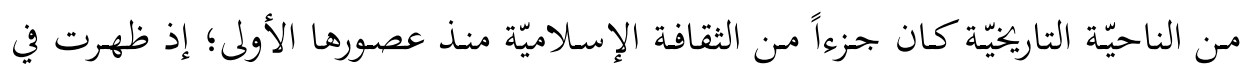
الدوائر المعرفيّة والأكاديميّة للفكر الإسلاميّ -منذ بداية الدية القرن الثالث الهجريّّ- كتابات

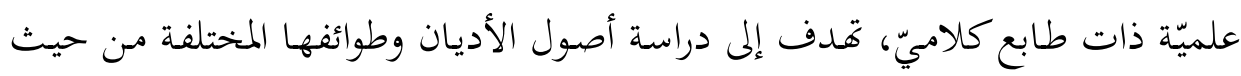
معرفة تواريخ نشأقها ومعرفة أفكارها العقديّة والفكريّة. ولا يلبث القارئ لدراسات علماء

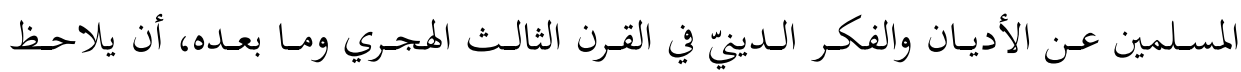

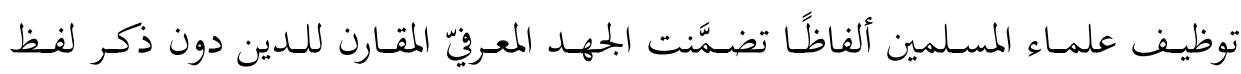

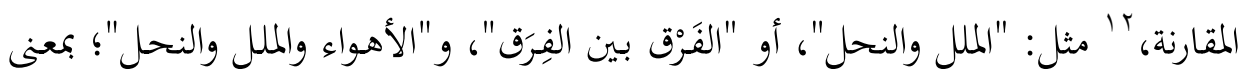

- الشهرستاني، أبو الفتح محمد بن عبد الكريم. الملل والنحل، صححه وعلق عليه: فهمي محمد، بيروت: دار

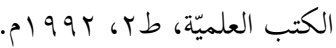
- البغدادي، عبد القادر بن طاهر . الفرق بين الفرق، القاهرة: درا المعرفة، . .9 ام. 
أهـم وظّفِوا مفهوم علم مقارنة الأديان دون ذكر المصطلح. وهؤلاء وإن لم يـكروا لفظ

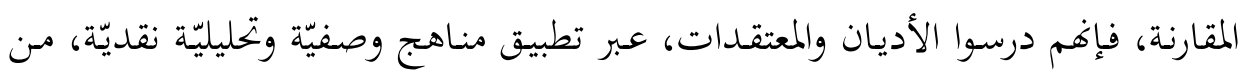

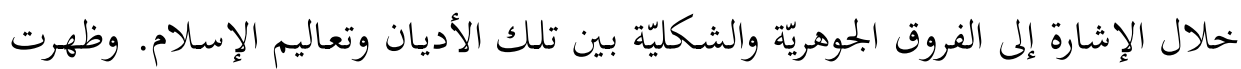

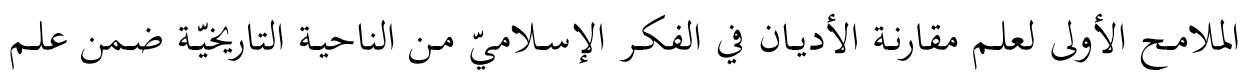

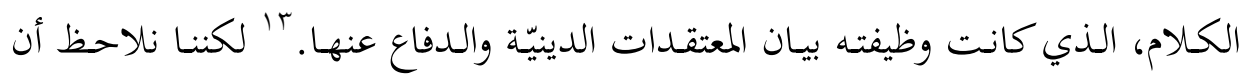
هذا العلم اكتسب استقلاليته وبـأ يأخحذ مكانته العلميّة على يـد العامريّ (ت: المبهـه والبيروني (ت: . عـهـ) وغيرهم مـن عمالقـة تاريخ الفكـر الإسـلاميّ، الذين أدركوا قصور النّهج الجدليّ وعدم جدواه في دراسة المعتقدات الأخرى.

وونلاحظ أهيّة التحديد الأوليّ "لغايته ومعالمه المنهجيّة"، قبل تحديد مفهوم هذا العلم لدى علماء مؤرّخة الأديان في الفكر الإسلاميّ. وعند تحديده لمفهوم هذا العلم في كتابه

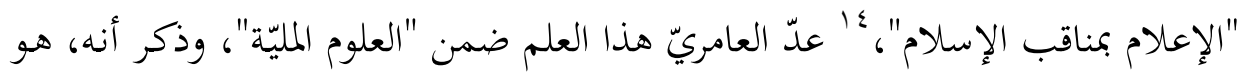

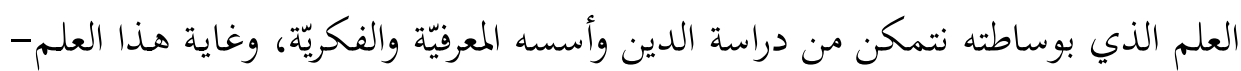

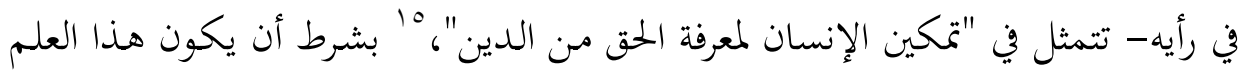

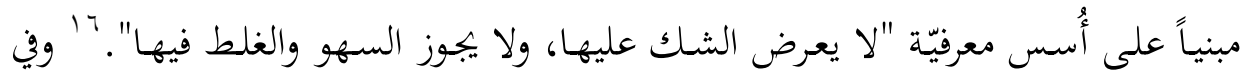

- ابن حزم، أبو عحمد علي بن أمد. الفصل في الملل والأهواء والنحل، تحقيق: عحمد بن إبراهيم نصر، وعبد

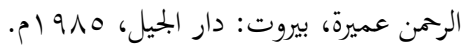

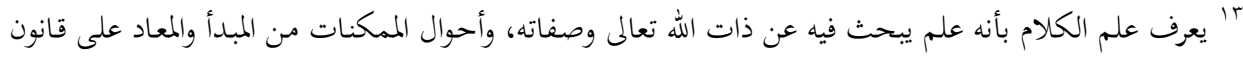

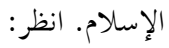

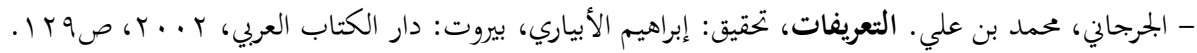

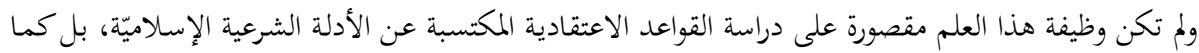

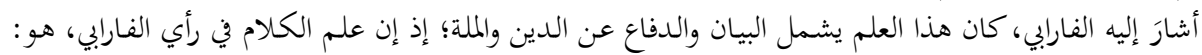

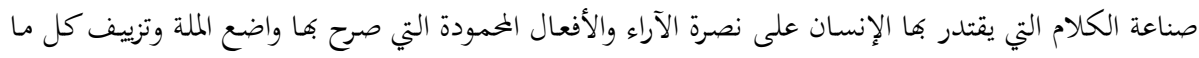

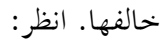
- الفارابي، أبو نصر محمد بن محمد. إحصاء العلوم، حققه وقدم له وعلق عليه: عثمان أمين، القاهرة: مكتبة

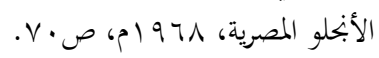

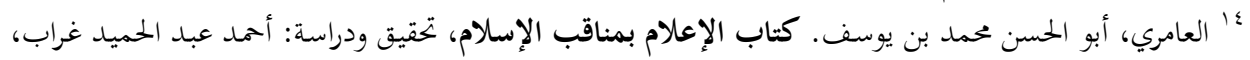

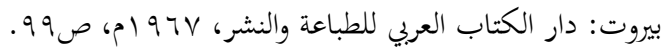

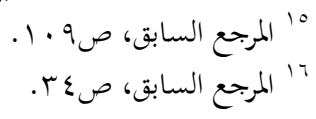


رأيه أن النزعات الفكريّة المتطرفة؛ (الإلحاد والجحود) غير بحدية في دراسة الدين، لكوها

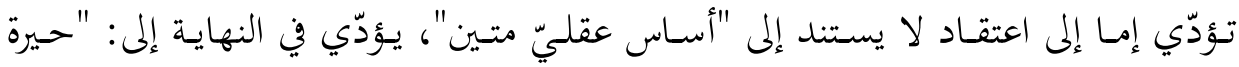

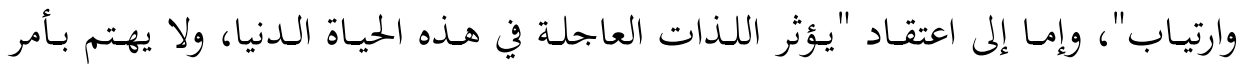

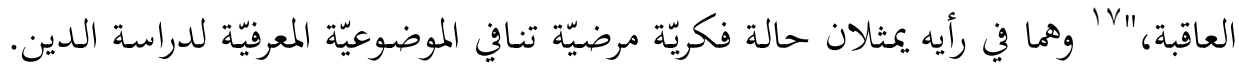
ومن أجل مراعاة الموضوعيّة العلميّة في الدرس المقارن للدين، جعل العامريّ العقل مقياساً

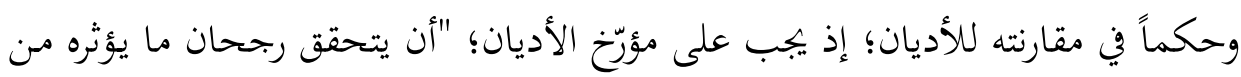

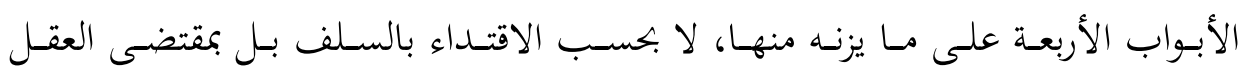

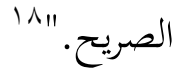
ورسـم العـامري المعالم الأساسيّة للدّراسـة الموضـوعيّة للتراث الدينيّ، واشـترط أمرين

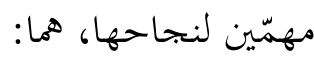

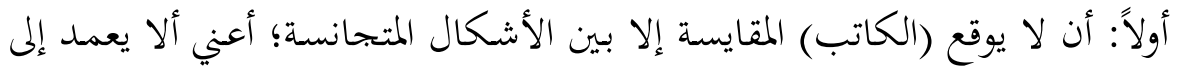

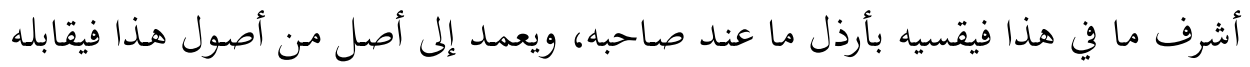
بفرع من فروع ذاك. ثانيـاً: ألا يعمـد إلى خلّة موصـوفة في فرقـة مـن الفـرق، غـير مستفيضـة في كافتهـا،

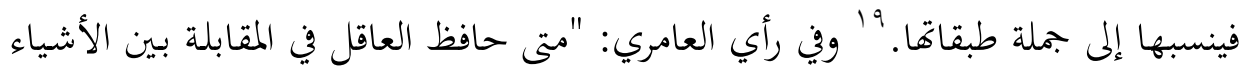

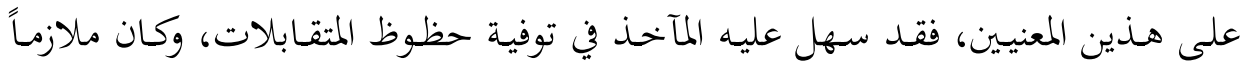

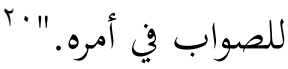

أمـا العـالم المسلم، أبو الريهان البيروين (ت: .عءهـ)، الذي وصفه المستشرق الألماني

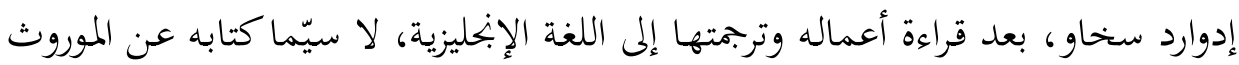

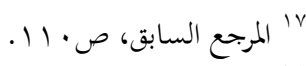

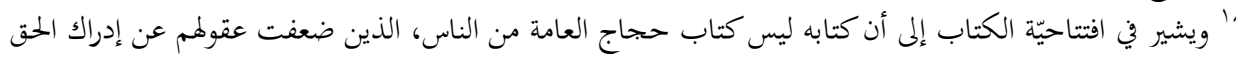

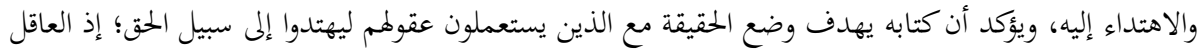

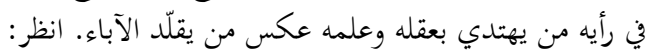

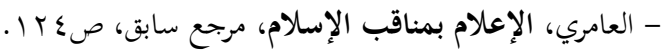

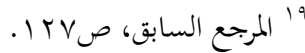

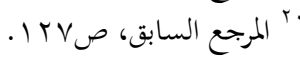




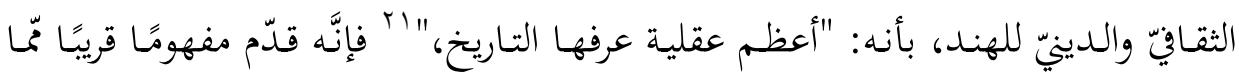

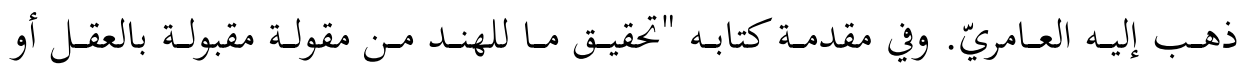

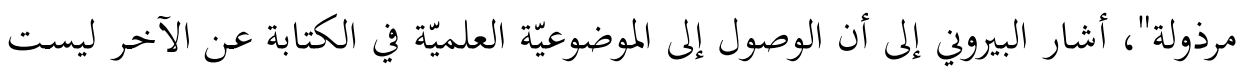

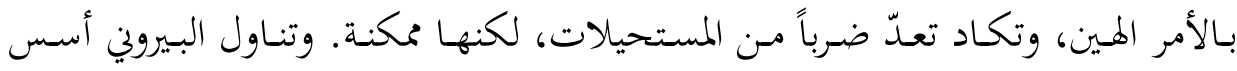

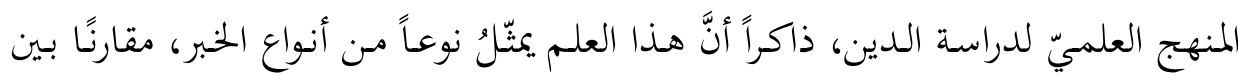

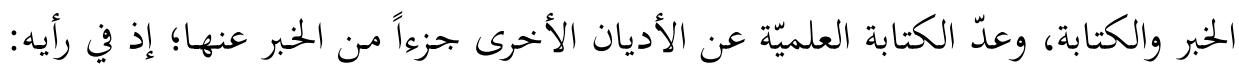

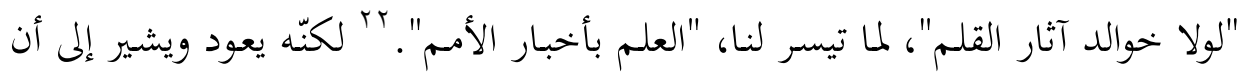

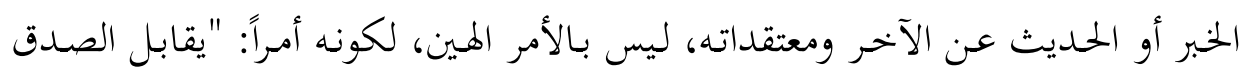

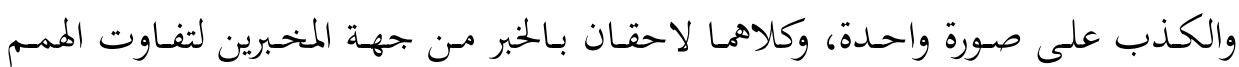

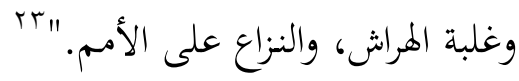

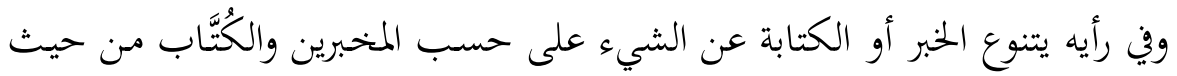

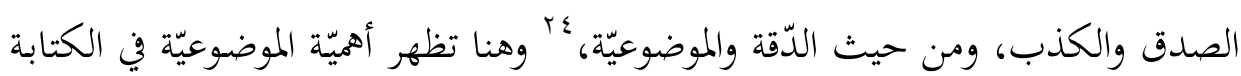

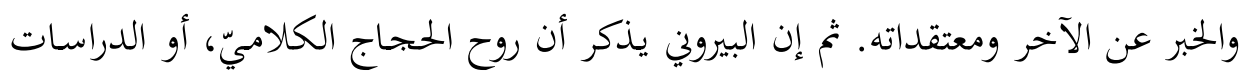

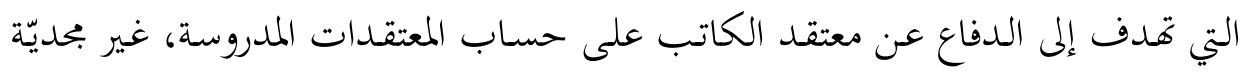

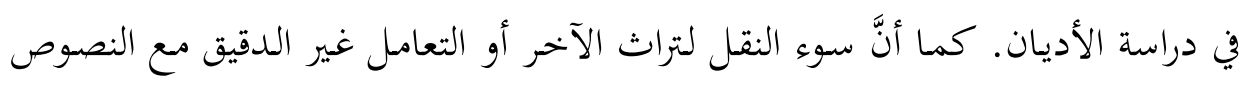

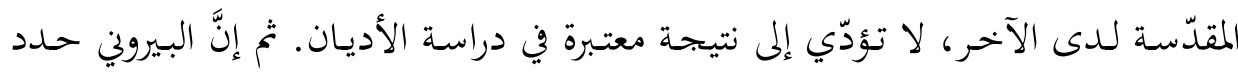

${ }^{21}$ Edward C. Sachau, Al-Biruni's India: An account of the religion, philosophy, literature, geography, chronology, astronomy, customs, laws and astrology of India about AD 1030, (New Delhi: Oriential Books Reprint, 1983).

rr البيروني، أبو الريحان محمد بن أحمد. تحقيق مـا للهنـد مـن مقولة مقبولة في العقل أو مرذولة، بيروت: عـالم

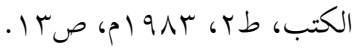

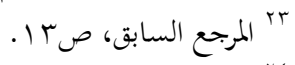

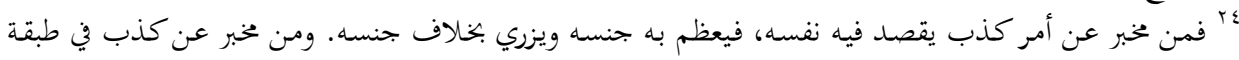

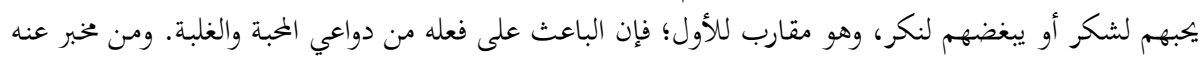

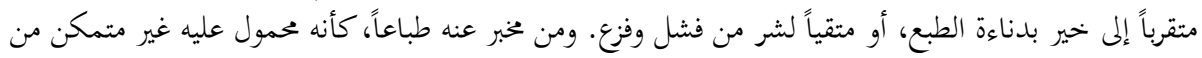

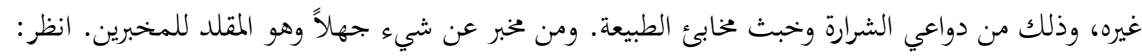

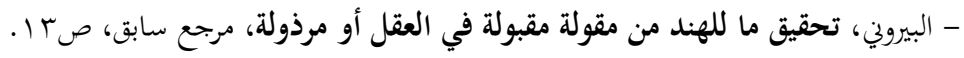


المعالم الأساسيّة لمذا العلم بـ: "الصدق والأمانة" العلميّة في نقل الأخبار ونقدها، وعدم

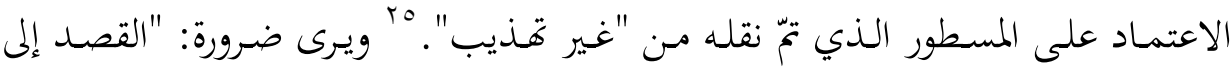
الحكاية البحردة، من غير ميل ولا مداهنة،" "جابي تحليل النصوص المقدسّة والتراث الثقافيّ

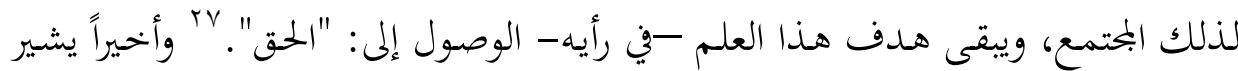
البيروين إلى عدم جدوى الحجاج الكالاميّ في هذا المحال، فينأى بنفسه عنه بقوله: "وليس الكتـاب كتـاب حجـاج وجـدل حتى أستعمل فيـه بـإيراد حجـج الخصوم ومناقضـة الزائغ مـهـم عن الحقق، وإنما هو كتاب حكاية فأورد كالام الهند على وجهه، وأضيف إليه مـا

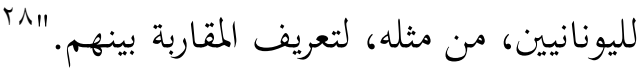

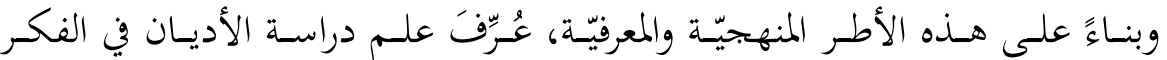

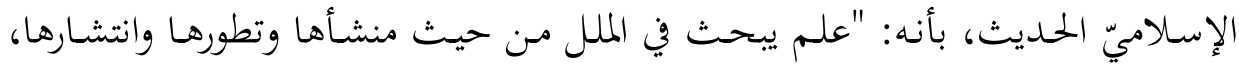

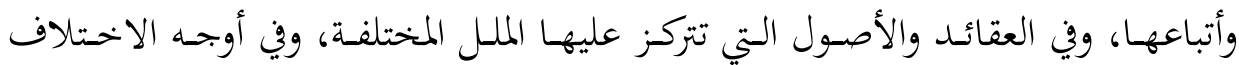

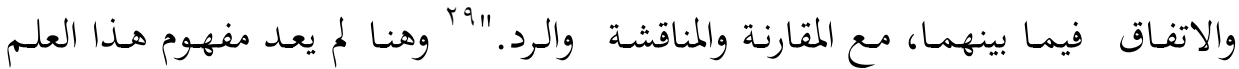

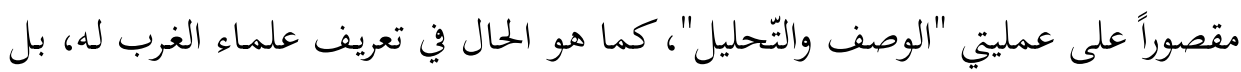
تضمّن عناصر إضافيّة مثل "المناقشة والردّ"، وهي عناصر ذات طابع معياريّ يتجاوز بها

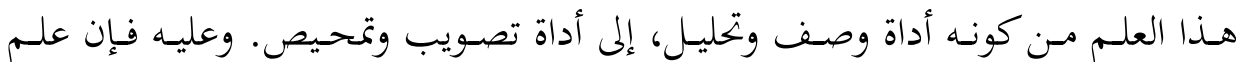

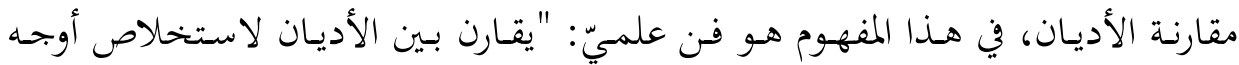
الشبه والاختلاف بينهم، ومعرفة الصحيح منها والفاسد؛ إظهارًا للحقيقة [الدين] بأدلة

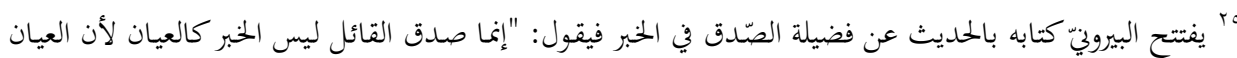

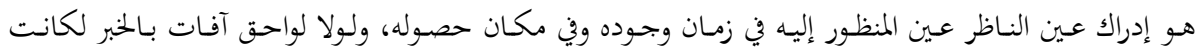

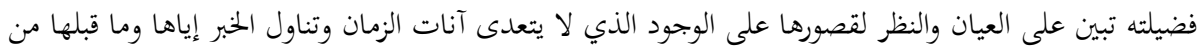

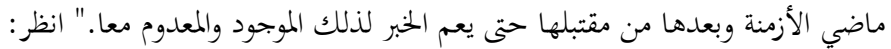

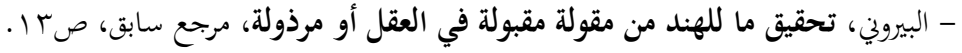

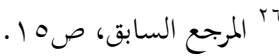

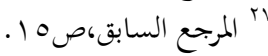

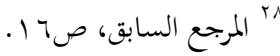

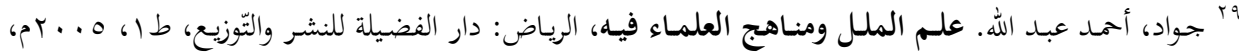




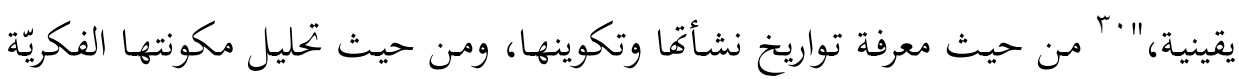
والعقديّة، وتأثيرها الاجتماعيّ، ومواطن انتشارها وأتباعها.

\section{ثانياً: علم دراسة الأديان وسؤال الإمكان}

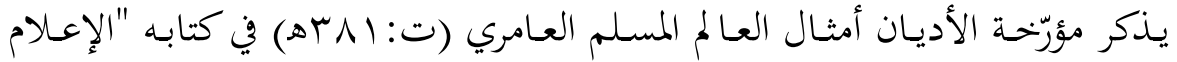

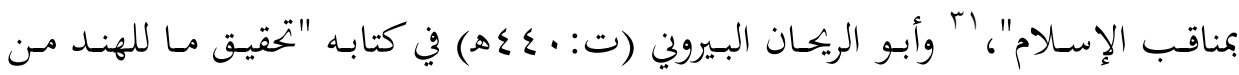

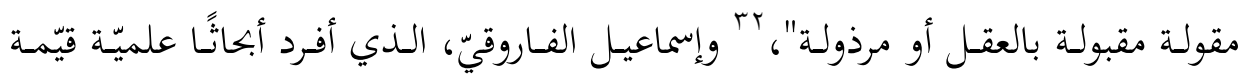

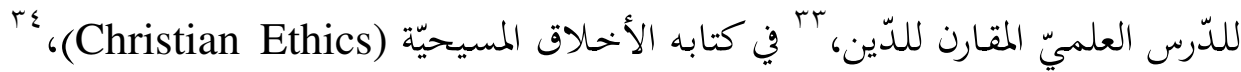

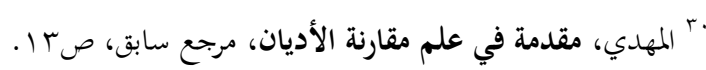

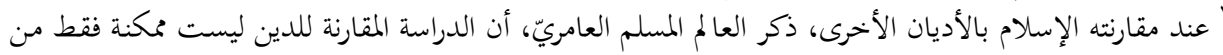

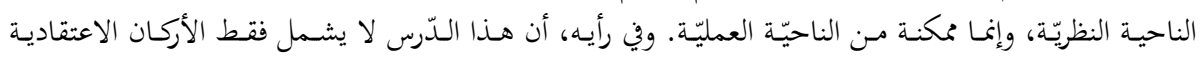

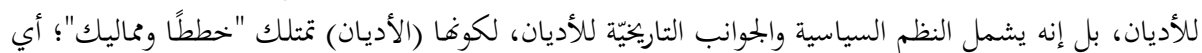

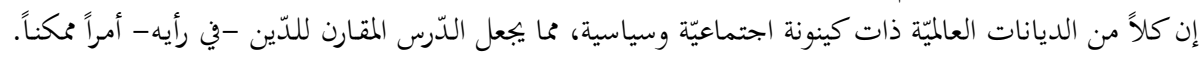

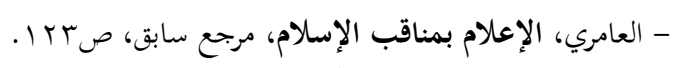

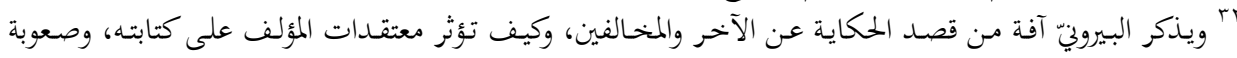

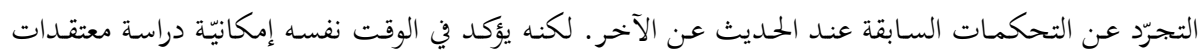

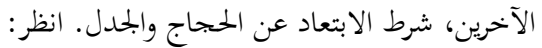

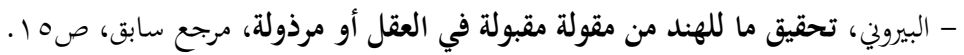

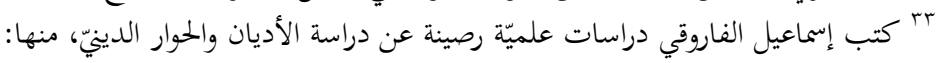

- al Faruqi, Isma'il Raji. Christian Ethics, Montreal: McGill University Press, 1967.

- al Faruqi, Isma'il Raji. Islam and Other Faiths, Edited by Ataullah Siddiqui, Leicester: The Islamic Foundation, 1998.

- al Faruqi, Isma'il Raji. Trilogue of Abrahamic Faiths, Herndon, VA.:

International Institute of Islamic Thought, 1991.

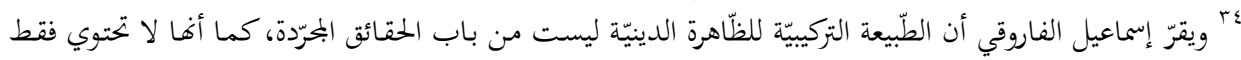

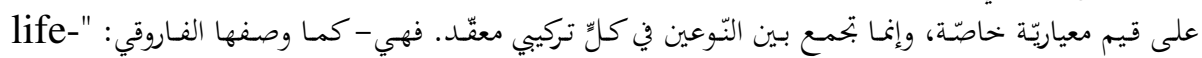

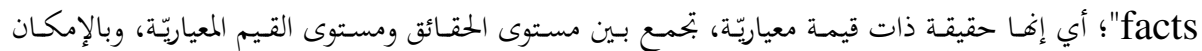

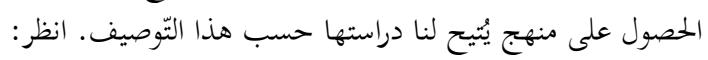

- al Faruqi Christian Ethics, opt, p1. 
وأريـك شـارب في مدونتـه "تـاريخ مقارنـة الأديـان"، وجـوردن في كتابـه "مقارنـة الأديـان: جذورها وتطورها"، وغيرهم ممن درسوا الفكر الدينيّ قديمًا وحديثًا، إمكانيّة صياغة منهج علميّ موضوعيّ لدراسة الأديان ومعتقدات الآخرين، مع إقرارهم بالتعقيدات والصعوبات التي في طريق ذلك.

\section{ا ـ إمكانيّة الحصول على المنهج المقارن للدين:}

ومع إقرار مؤرّخة الأديان بإمكانيّة الحصول على منهج علميّ لدراسة الأديان على نحو علميّ وموضـوعيّ، إلا أنّ هنـاك اعتراضـات وتسـاؤلات تثار مـن وقـت لآخـر حسول

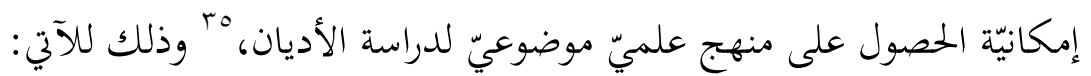

أ. لكـون الـدّين يشـمل مسـائل غـير موضـوعيّة تتعلـق في بحملهـا بقضـايا نفسـيّة وروحيّة (جوّانيّة) يصعب على الباحـث تقويمها على نحو موضسوعيّ مـن خهلال المنـاهج العلميّة التجريبيّة. بr أضف إلى ذلك أن مقارنة الأديان عمليّة ذات طرفين؛ ثقافة الكاتب لبك وتكوينه الفكريّ والمعريّّ من جهة، وضرورة التعامل مع المعتقدات المدروسة بموضوعيّة،

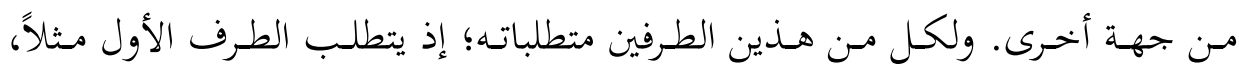
الأخــ بالحسبـان المعتقـدات السـائدة في ثقافـة الكاتـب وتراكماتـه الفكريّة والمعرفيّة قبـل دراسته للأديان الأخرى، التي تؤثّرَّ في الغالب في طريقة تفكيره وتصوراته عن ثقافة الآخر ومعتقداته. أمـا الطرف الثاني فإنـه يتمثل في الاهتمـام بالأديـان التي يدرسـها الباحـث،

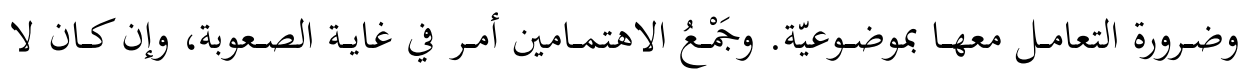
يصل حد الاستحالة.

- زين، إبراهيم حمّّد، "الحوار الإسلامي المسيحي في السودان: أسس معرفية ومعضلات تاريخية"، الموقع: http://www.mubarak-inst.org

35 The study and classification of religions, in Eencyclopaedia of Britannica, London: Encyclopaedia of Britannica, Inc. $15^{\text {th }}$ ed., v.26, p.549

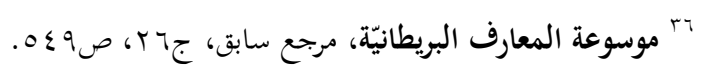


ب. يضيف بعضهم اعتراضًا آخر ويقول: إذا كان من المستحيل أن يؤمن الإنسان

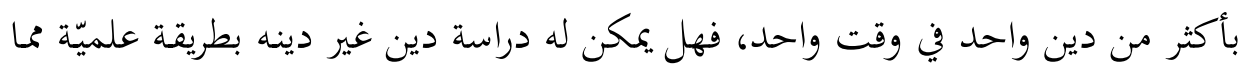
لم الم يؤمن به.

ت. ومما يعقّد الموضوع، هو أن طريقة المعرفة والاهتداء إلى حقيقة التعاليم الدينية من

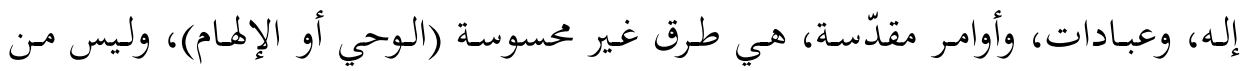

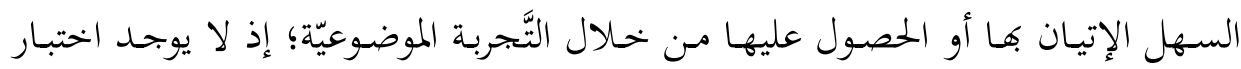
موضوعيّ بطريقـة الحصول على المعارف الدينيّة. وعليه فكيف يمكـن الجززم أنه بمقدورنا

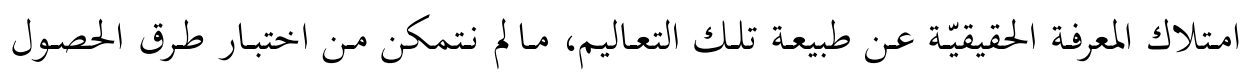

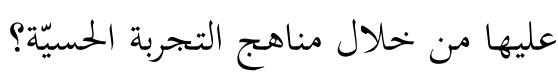

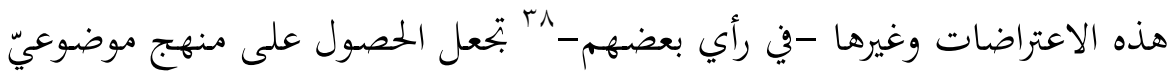
لدراسة الدّين أمراً شبه مستحيل. لكـن، ومهع أن هـذه الاعتراضـات تعبّر عن تسـؤلات جـادّة تتعلق بمسـألة الحصـول

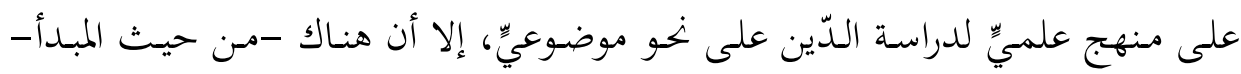

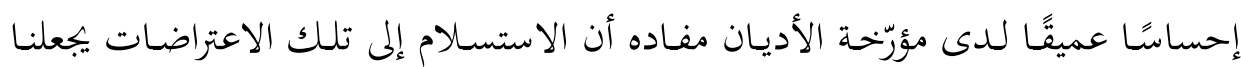

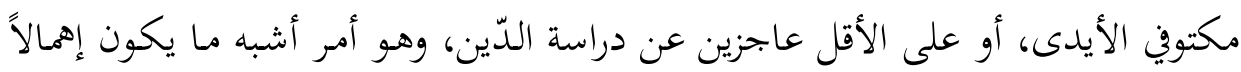

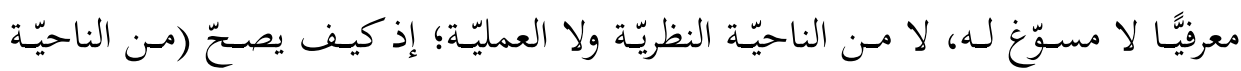

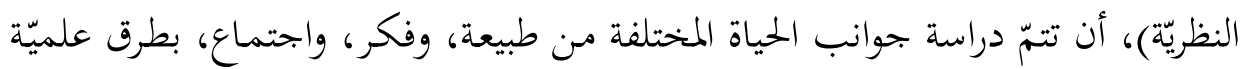

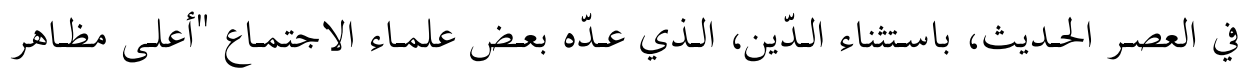

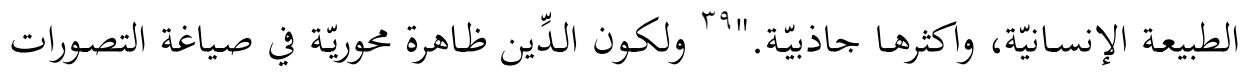

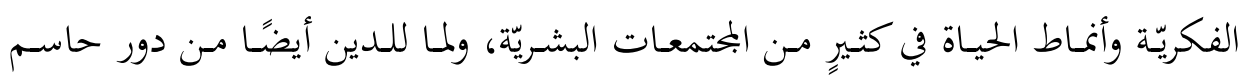

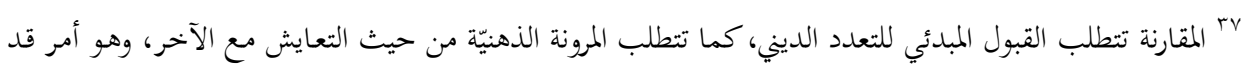

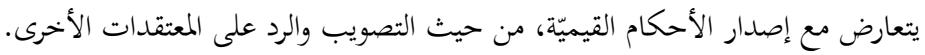

38 The study and classification of religions", in Eencyclopaedia of Britannica, opt, v.26, p.549

وَ" شالي، فيلسيان. موجز تاريخ الأديان، ترجمه عن الفرنسيّة: حافظ الجماليّ، دمشق: دار طلاس للدراسات والترجمة 
وفاعل في تشكيل معا لم الحياة المعاصرة، فعليه يجب: "على أهل الذكر والفكر منّا صياغة

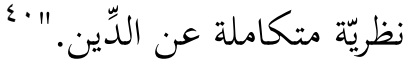

ومسن الناحيّة العمليّة، قـدّمت منـاهج دراسـة الأديـان أُكُلهـا المعرويّ في بجـال دراسـة

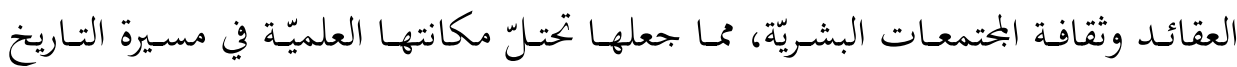

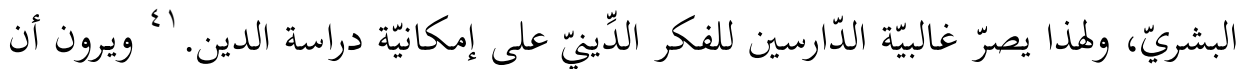

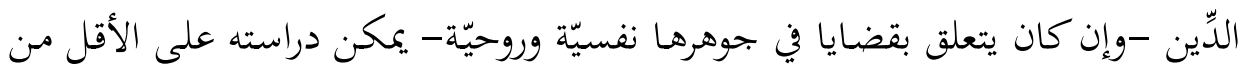

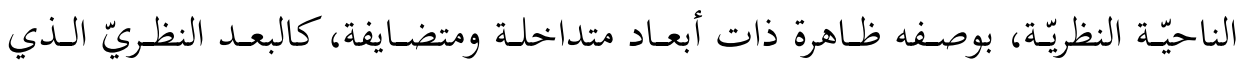

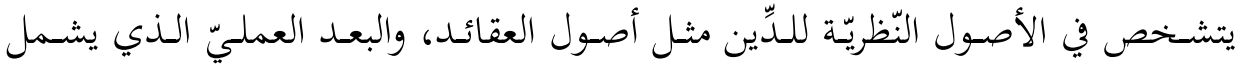

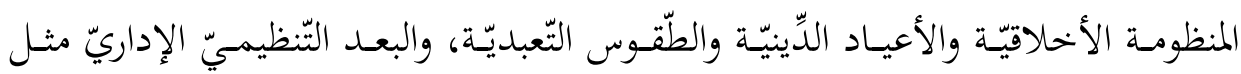

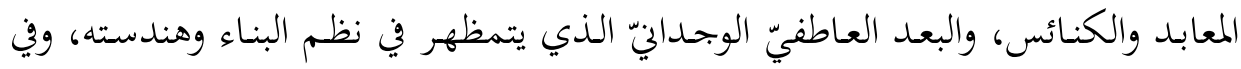
الشّعر، والموسيقى، والفنون عموماً.

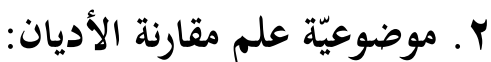

يرى علماء دراسة الأديان إمكانيّة بتحاوز هذه الإشـاليّة، عبر ترسيم أُطر منهجيّة

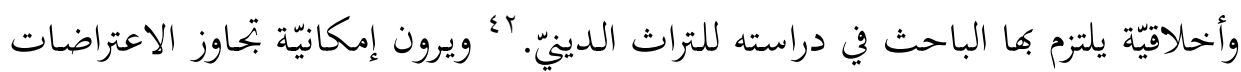

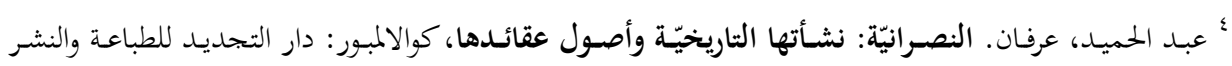

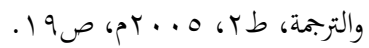

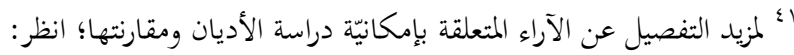

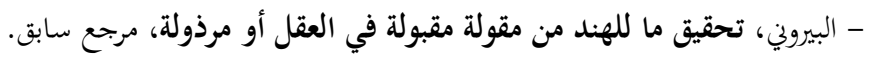
- العامري، كتاب الإعلام بمناقب الإسلام، مرجع سابق.

- Sutherland, Stewart. The world's religions, London: Routledge, 1988 , p.7.

- Smart, Ninian. The world's religions: old traditions and modern transformations, England: Cambridge University Press, 1989, p12-21.

- Neusner, Jacob, the Way of Torah: An Introduction to Judaism California: Wadsworth Pub. Co., 1979, p.3.

- Eliade, Mircea and Kitagawa, Joseph, The History of Religions: Essays in Methodology, Chicago: University of Chicago Press, 1959. 
الثلاثة المذكورة آنفًا المتعلقة بمدى موضوعيّة المنهج المقارن للدين والحصول عليه، في حالة توفر شروطٍ ثلاثة، ذكرها أريك شارب، في كتابه تاريخ مقارنة الأديان، وهي: أ. و وجود رغبة حقيقيّة لدراسة الأديان تسعى إلى فهم المكونات الفكريّة والثقافيّة للأديان المقارنة. ب.تـوفر المـادة العلميـة سـواء كانـت هـذه المـادة أساسيّة أو ثانويّة عـن المعتقـدات والأفكار الدينيّة التي تحت الدراسة والبحث. لبحه

ت. وجود منهج علميٍٍ مقبول، يقوم الكاتب مـن خلاله بترتيب المعلومات بطريقة معقولة. باءوفي حالة توفر هذه الشروط، يمكن للباحث في الدرس المقارن للدين -في رأي

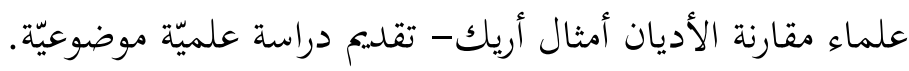

لكن هذه الشروط في حد ذاتا تبدو فضفاضة ولا تخلو من ملاحظات منهجيّة؛ إذ

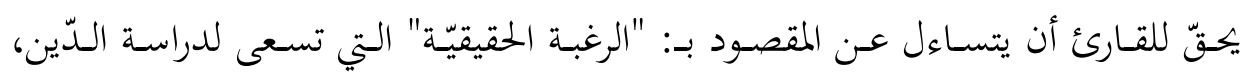

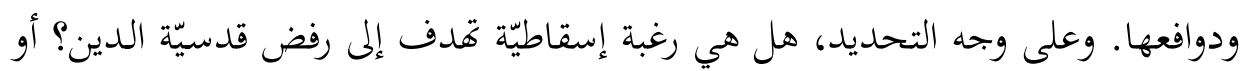

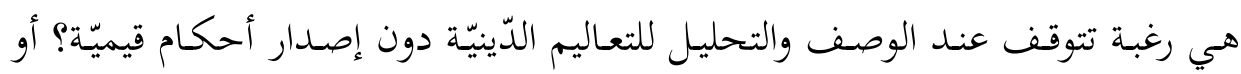
هي رغبـة تتجـاوز الوصف والتحليل إلى إصـدار أحكام قيميّة تصـنّف الأفكار الدينيّة

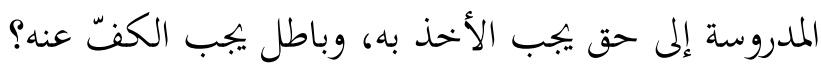

والرغبة الإسقاطيّة هي تلك التيارات الوضعيّة التي أنكرت قدسيّة الدين، والتي درس

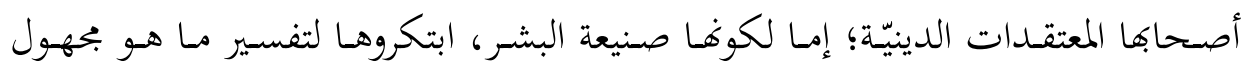

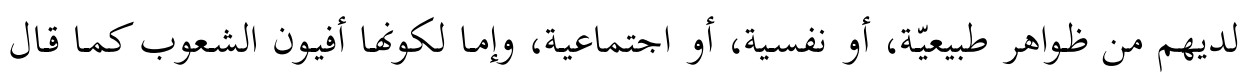

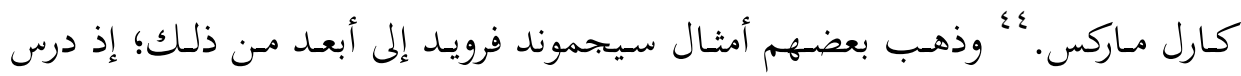
الدين بوصفه ظاهرة نفسيّة، وتوصّل إلى أن الدين في جوهره: "استجابة وردّ فعل لحالة

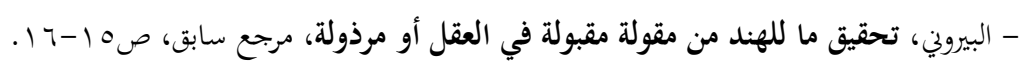

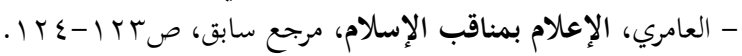

${ }^{43}$ Sharpe, Eric J. Comparative Religion: A History, opt, p.2 ${ }^{44}$ Goldstein, Warren S. Marx, Critical Theory, and Religion: A Critique of Rational Choice, Boston: Brill, 2006. 
عصابية نفسية لا غير،"ه؛ ودوركايم الذي درس الظاهرة الدينيّة بوصفها ظاهرة اجتماعيّة، وجزم بأن الدّين: "خداع اجتماعيّ، "آ؛ وغيرهم من الذين أسقطوا الدّين من الاعتبار. ولا شـك في أن هؤلاء كانـت لديهم رغبـة حقيقيّة في دراسـة الظّاهرة الدّينيّة، لكـن

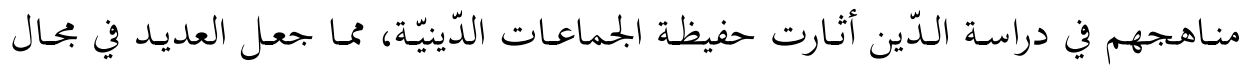
الدّين المقارن، يشكّكون في قدرة تلك المناهج على تقديم دراسات يُعتدّ بها عن الدّين. وفي مقابل الرغبة الإسقاطيّة للدّين، نلاحظ وجود فريق مـن علماء مؤرّخة الأديان

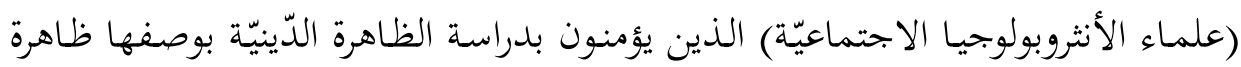

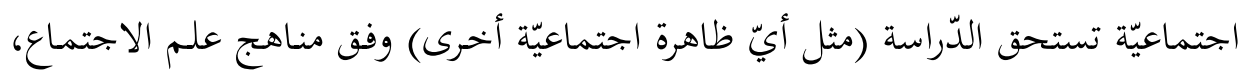

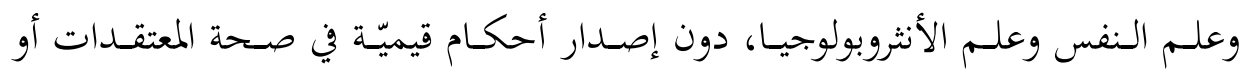

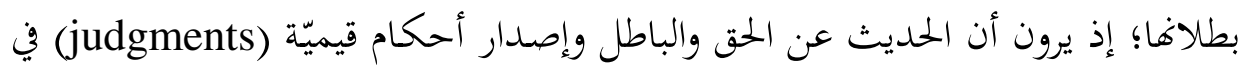

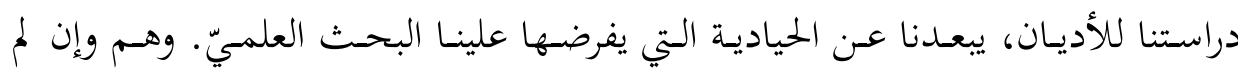

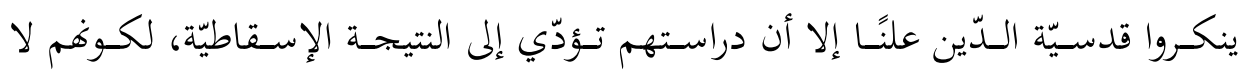

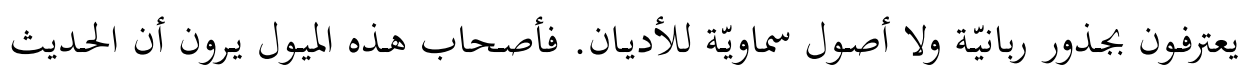

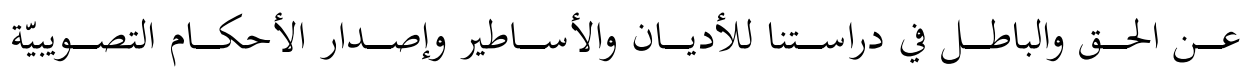
يبعدنا عن الحيادية التي يفرضها علينـا البحث العلمي، (evaluative judgments)

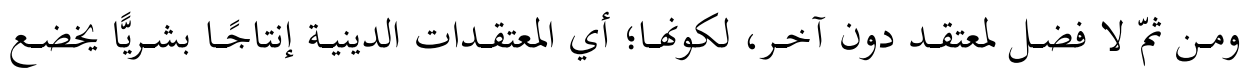

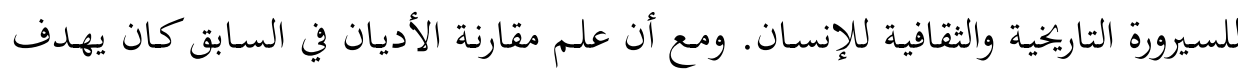

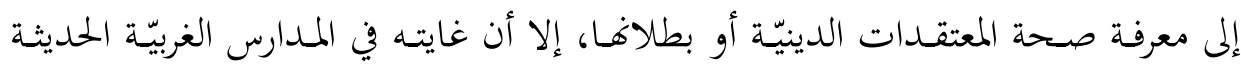
باتت تنحصر في الوصف والتحليل من خلال مناهج علم الاجتماع، وعلم النفس، وعلم

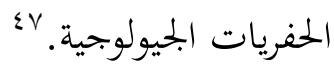

45 Freud, Sigmund. The future of an illusion, translated and edited by James Strechey, London: W.W. Norton and Company, 1961.

${ }^{46}$ Durkheim, Emile. Elementary Forms of the Religious life, translated by Carol Cosman, Oxford: Oxford University Press, 2001.

${ }^{47}$ The study and classification of religions, Encyclopaedia of Britannica, opt, v.26, p.549 


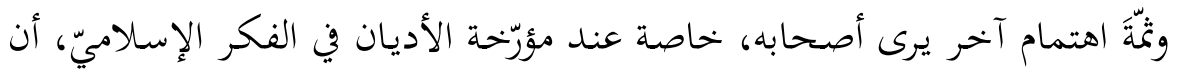

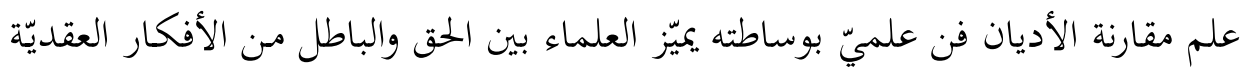

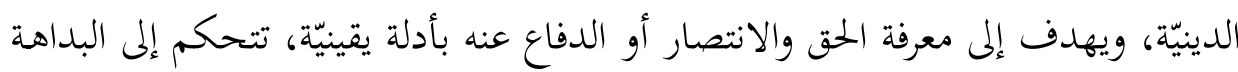
العقليّة تارةً، أو النصوص الصحيحة الموحى بها تارةً أخرى. وعلى كلٍّ وكيفما كان الأمر، فإن ترجيح الاحتمال الأوّل يؤدّي إلى نتيجة سلبيّة،

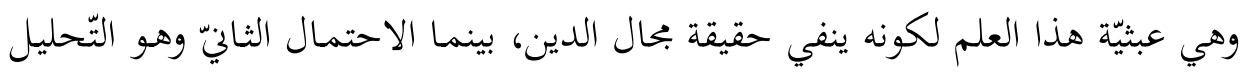

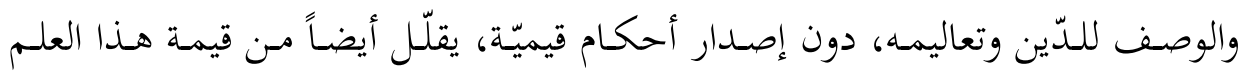

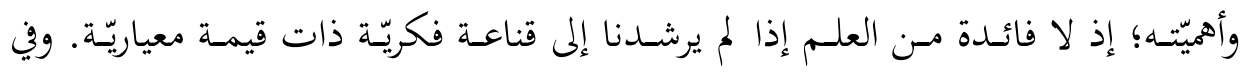

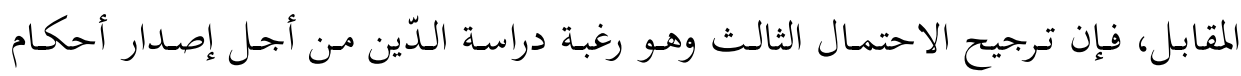

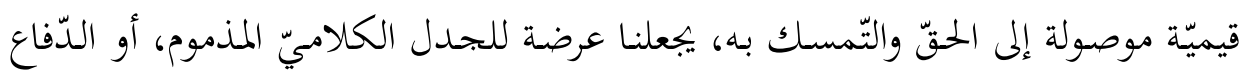

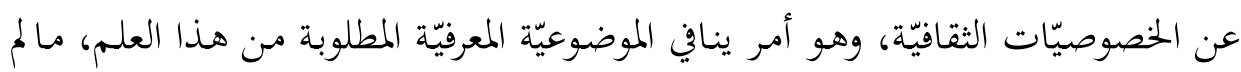

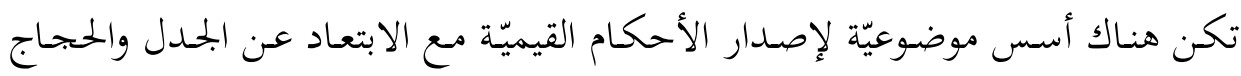

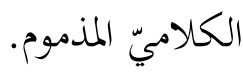

وإذا كان الأمر كذلك، فكيف يمكن لنا صياغة منهج موضوعيّ مقارن للدّين، لا

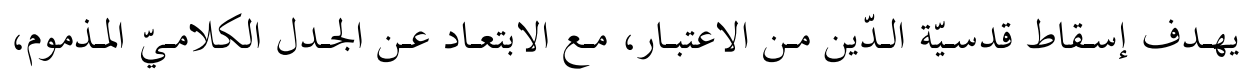

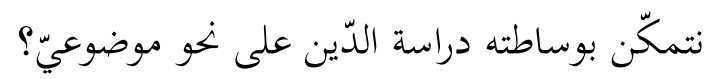

\section{r. ب. صياغة منهج مقارنة الأديان وغايته:}

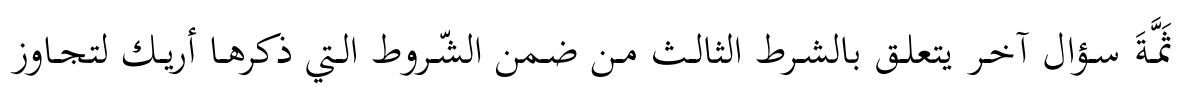

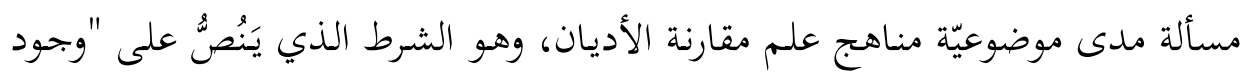

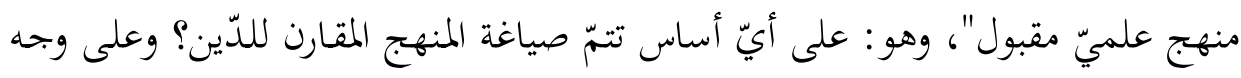

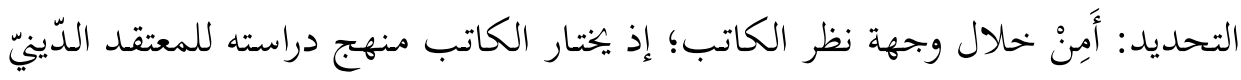

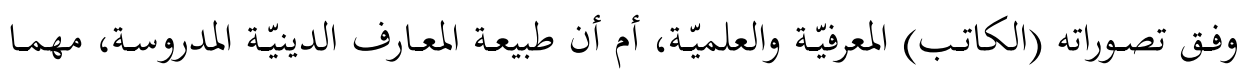

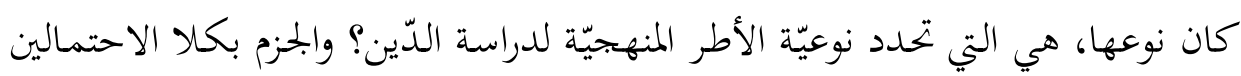

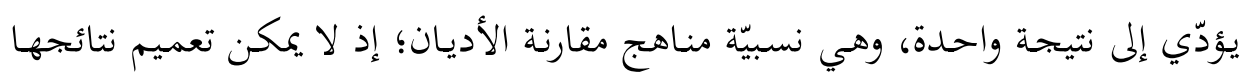


العلميّة، لكوفا تمثل في هذه الحالة؛ إما وجهة نظر الكاتب وتصوراته الفكريّة أو المعرفيّة

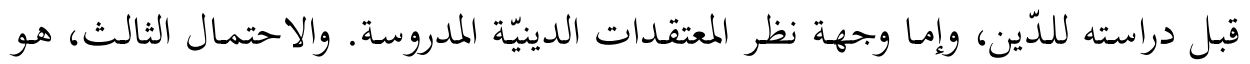

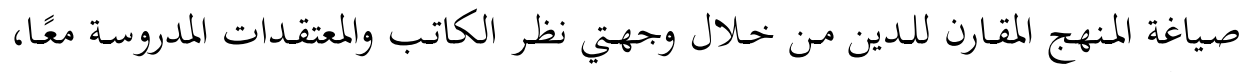

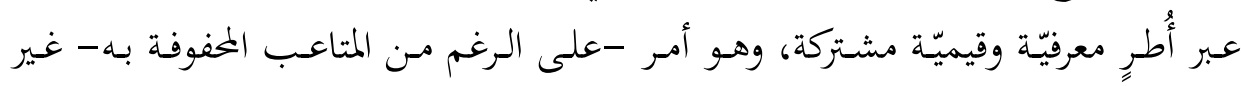
مستحيل. ويبـدو لي أن الاحتمـال الأخير هو مـا دعـا إليه المرحوم الفـاروقيّ في كتابه "أخهلاق

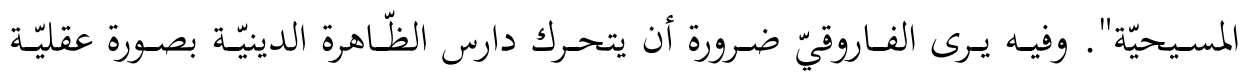

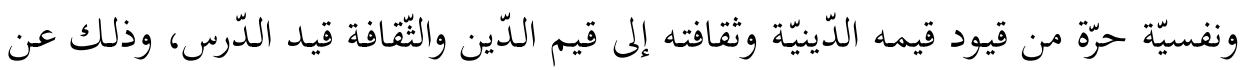

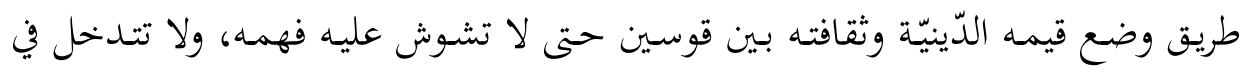

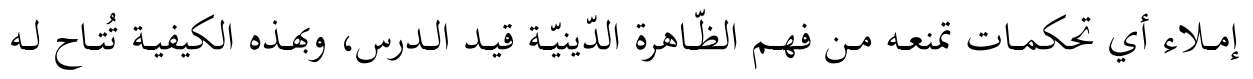
الفرصة أن يعيش مع الظاهرة الدينية قيد الدّرس مدة يستمع إليها وهي تخاطبه، وبالتالي

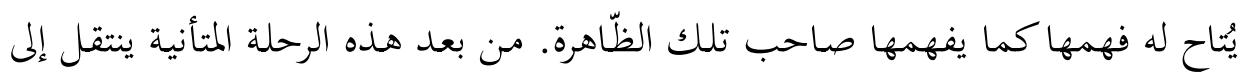

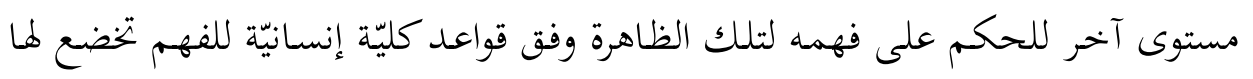
الظاهرة الدّينيّة. وبهذه الحركة الثلاثية: بداية بالّدين، والثقافة التي تنتمي إليها، ثم الظاهرة

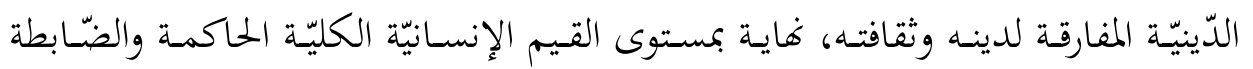

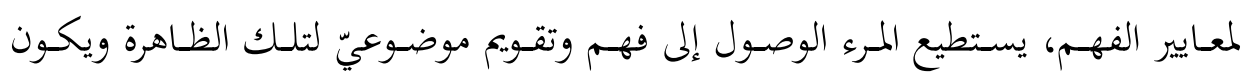

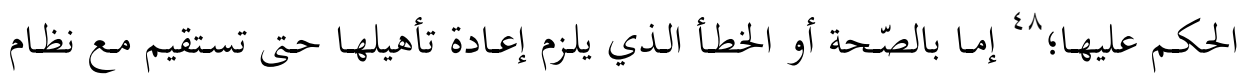
الفهم والحكم الموضوعيّ.

وهـذا المـنهج مثلمـا هـو صـالح لدراسـة الـدّين والثقافـة المفارقة، فهو كـذلك يصـلح

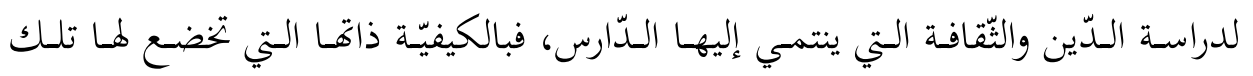
الثّقافات والديانات المفارقة، يخضع لها دين الدارس وثقافته، بالكيفية نفسها مـن الجرأة

${ }^{48}$ al Faruqi, Isma'il Raji. Christian Ethics, opt, p1. - زين، "الحوار الإسلامي المسيحي في السودان: أسس معرفية ومعضلات تاريخية"، مرجع سابق. 


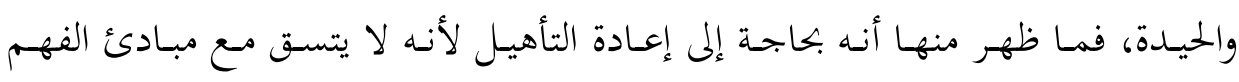

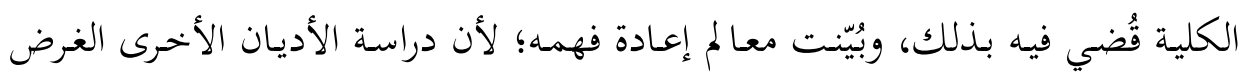

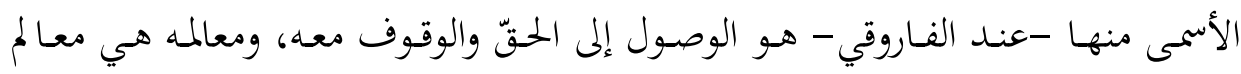

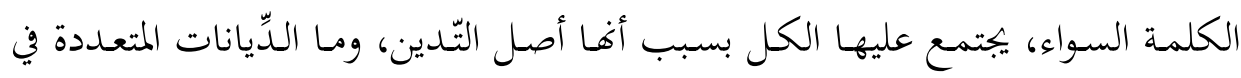

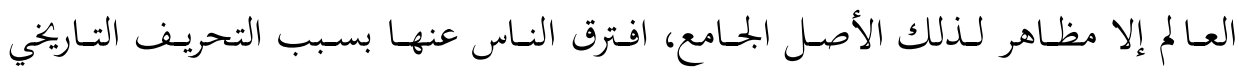

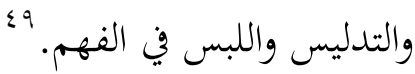

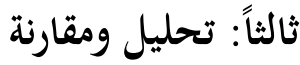

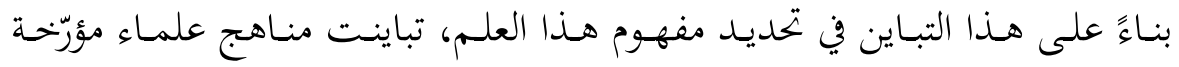

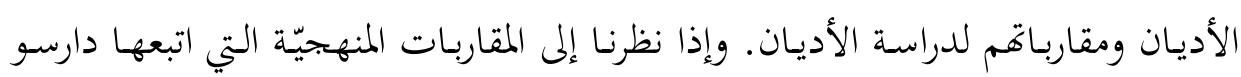

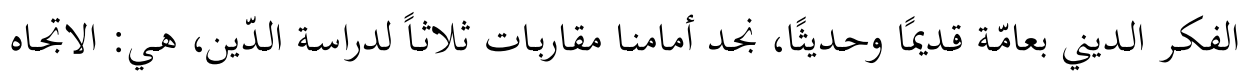

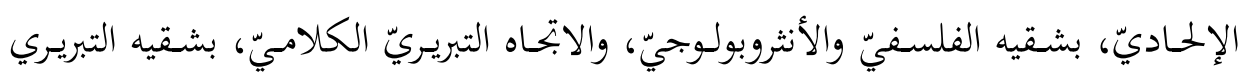

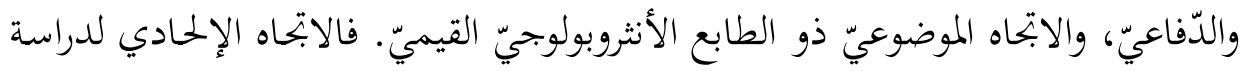

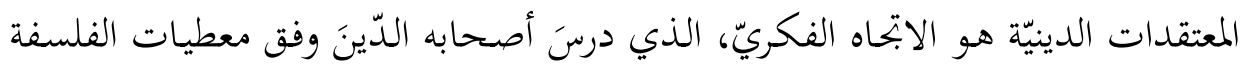

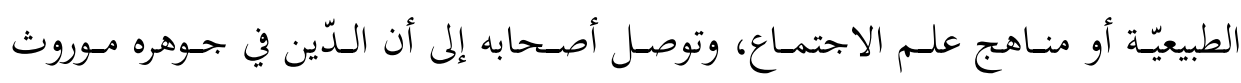

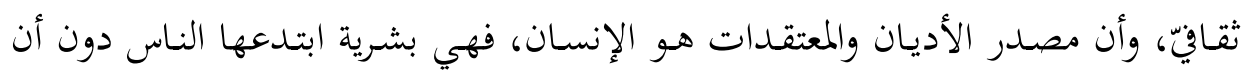

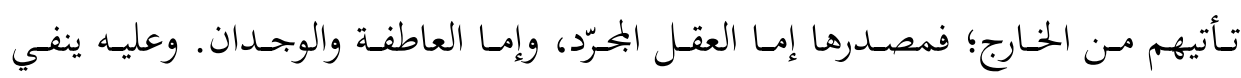

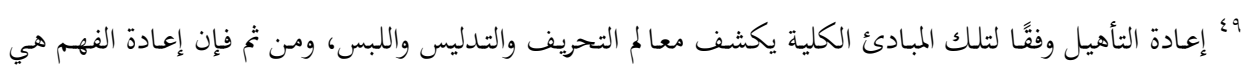

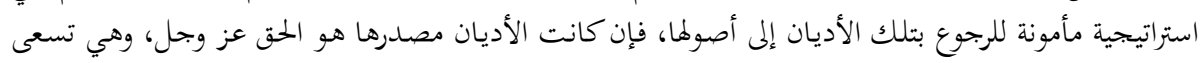

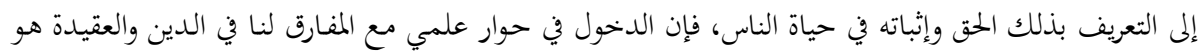

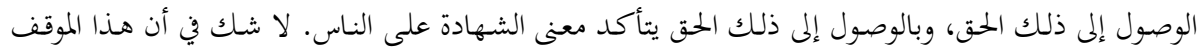

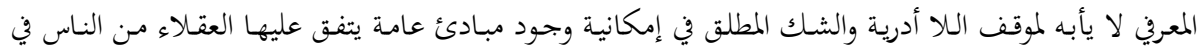

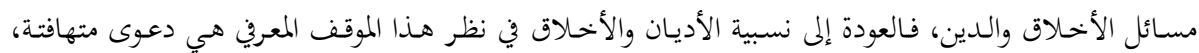

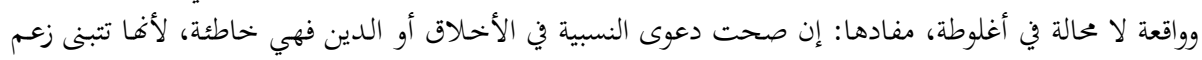

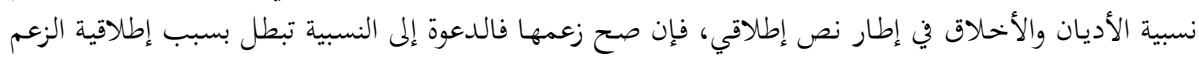

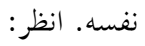
- زين، "الحوار الإسلامي المسيحي في السودان: أسس معرفية ومعضلات تاريخية"، مرجع سابق. 
أصسحاب هـــه المقاربـة، ظـاهرة الـدّين شـكالً ومضـمونًا، وينظـرون إليهـا نظـرة عدائيـة، لفقـدان التعـاليم الدّينيـة -ـفي رأيهــم- النسـق الـداخلي، ولكوغـا تتسـم بالتنـاقض وعـدم العقلانية، وبالتالي يجب أن يُسدل الستار عليها من غير رجعة. .

ومـن الناحيّة التاريخيّة يشير كثير مـن البـاحثين إلى أن الابتحاه الإلحادي لدراسة الدين ظهرت ملامحه الأولى في الفلسفة اليونانية، خاصة عند بروز الفلسفة الطبيعيّة، وبالذات

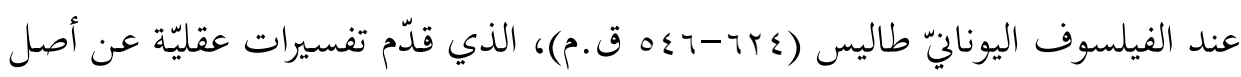
العـا لم وطبيعتـه، دون الرجـوع إلى التفسـيرات اللاهوتيــة أو الميثولوجيّـة للعـالم والحيـاة في اليونان. اهو ولم تتوقف المقاربة الازدرائية الإلحاديّة للتعاليم الدينية وقميشها عند الفلسفة الطبيعيّة اليونانيّة في الغرب، بل كما تشير إليه "كارن أرمسترونغ"، في كتابها تاريخ الإله: (A History of God) عشر، ومع التطور العلمي والتكنولوجي الذي شهده الغرب، بدأت بوادر تيارات فلسفيّة أعلنـت استقلالما مـن فكرة وجـود الحنالق الأعظه. هـذا العصر كان عصسر كارل مـاركس

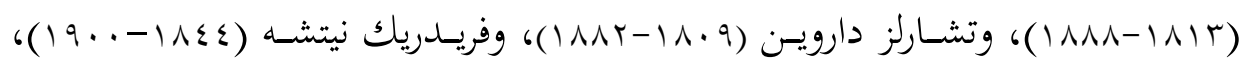

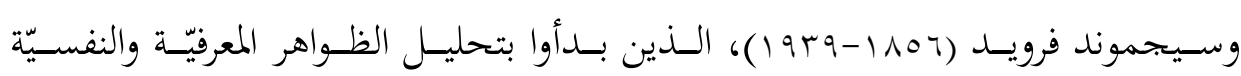
والاقتصاديّة والاجتماعيّة للإنسان بطريقة لم يكن لفكرة اللنالق الأعظم أي دور فيها.

ومن الذين ذهبوا إلى هذا المنوال الفيلسوف الاجتماعيّ الفرنسي أوجست كونت IV99) August Conpt

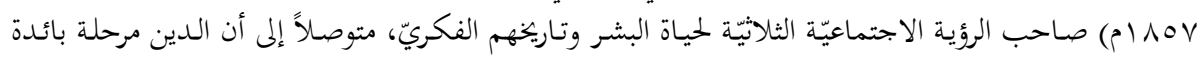

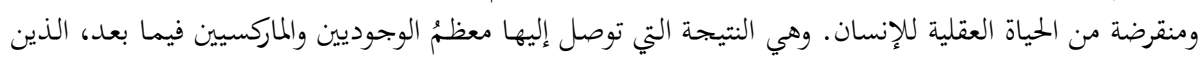

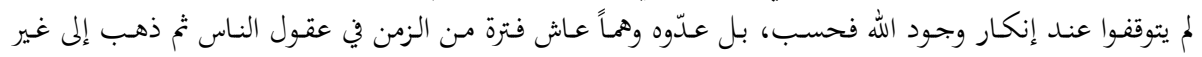

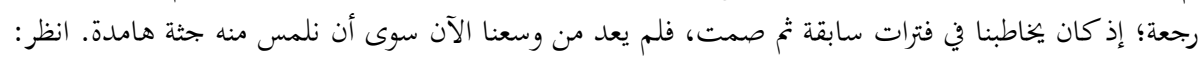

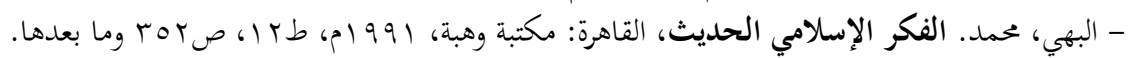

- Picering, Mary. Auguste Comte: An intellectual biography, England: Cambridge University Press, 1993, pp.562-569.

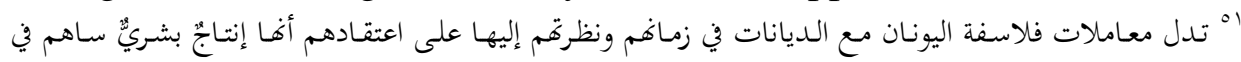

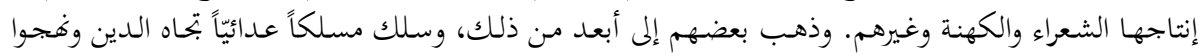

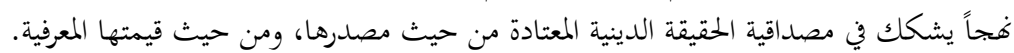
-r Armstrong, Karen. A history of God: The 4000 year quest of Judaism, Christianity and Islam, New York: Alfred A. Knopf, 1993, p.397 
وتتضمن المقاربة الإلحاديّة للدّين نوعين من المناهج، الأول منهما: مقاربة أصحاب

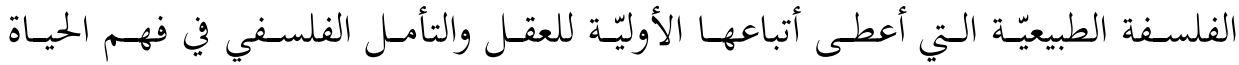
وتفسيرها، دون إعطاء أي وزن للتعاليم الدينية أو الوحي في معرفة عالم الطبيعة وما وراء

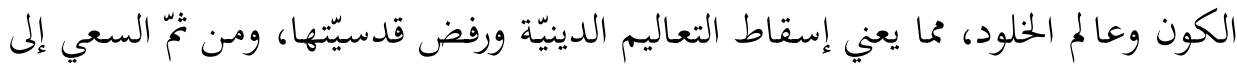

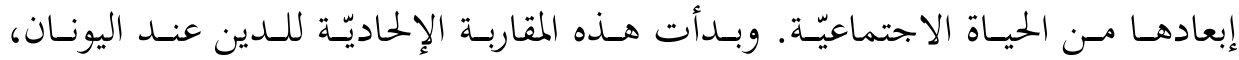

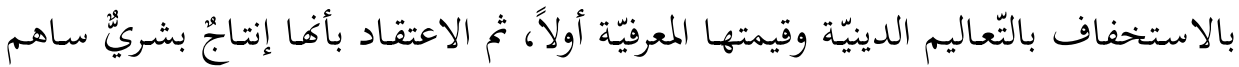
في إنتاجهـا الشّعراء والكهنـة وغـيرهم. وتطور هـذا الاستخففاف والتّشـكيك في قدسيّة

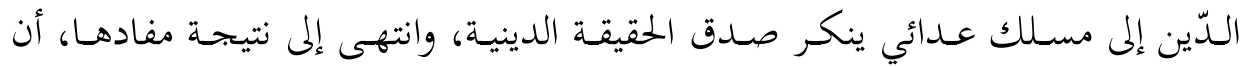

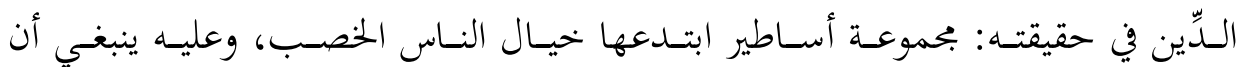

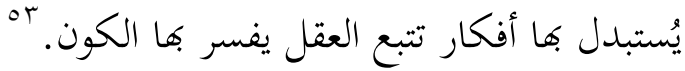

أمـا النـوع الثـاني للمقاربـة الإلحاديّة للـدين، فهي رؤيـة بعض علمـاء الأنثروبولوجيـا الثقافيّة، التي دعا أصحاها، إلى دراسة الدّين من منظار الدراسات الأنثروبولوجيّة بوصفه لئه

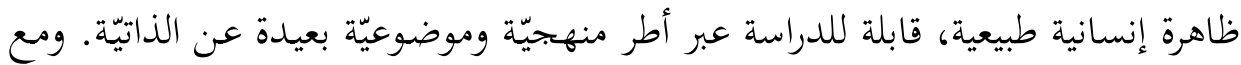

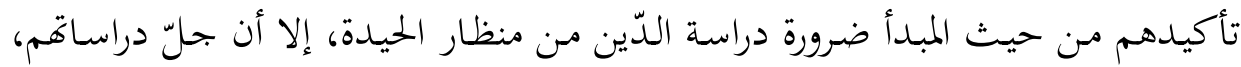
كانت لا تقرّ للدين بأصل مقدس (إلهيّ)، ولم يكن بمقدورهم التّمييز بين الدّين والسّحر

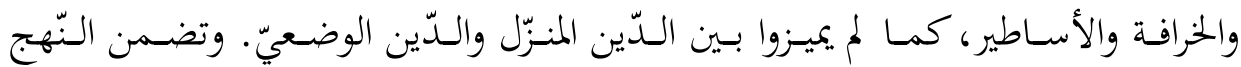

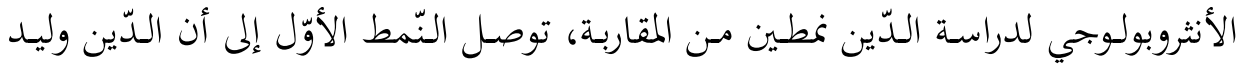

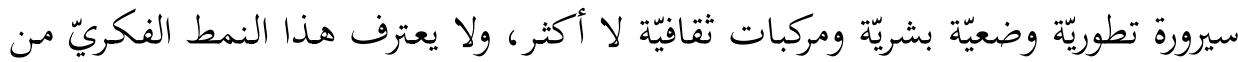

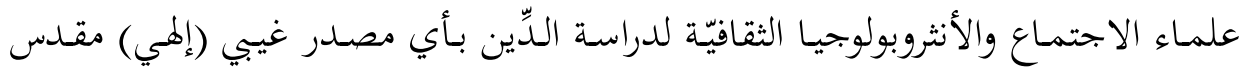
للدين، بل رأى هذا الفريق الدّين بأنه صنعة بشريّة مختلقة، وأنه أفيون للشعوب أو أو مظاهر

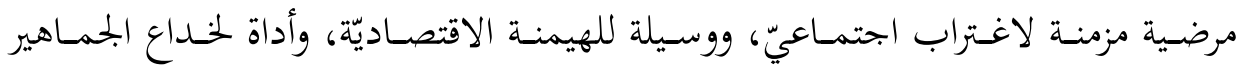

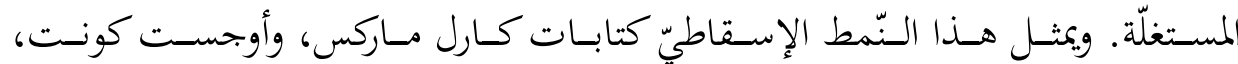

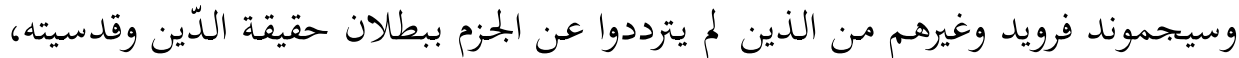

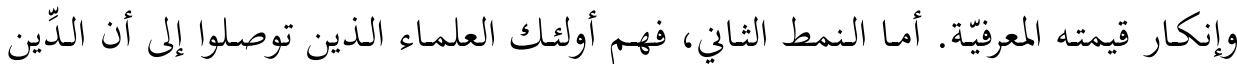


ظاهرة اجتماعية، ويمكن دراسة معالمها الظاهيّة والنفسيّة من خلال المناهج الاجتماعيّة،

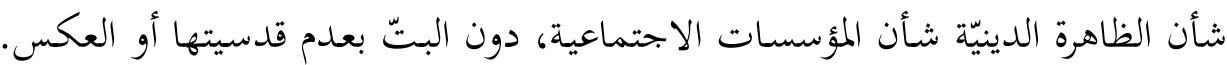

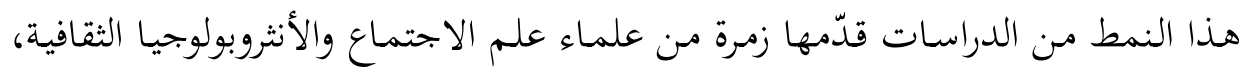

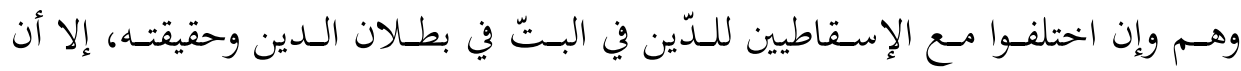
دراساقم لا تعترف للدّين بقدسية ولا أصول ربانيّة لوجوده، مما يعني النتيجة الإسقاطيّة نفسها.

ومقابل الابحاه الإلحاديّ الذي ينطلق من الرؤية العدائية للدين أو على الأقل ازدرائه لما، ينطلق أصحاب النّهج الإيمانيّ التبريريّ مـن منطلق الاعتقـاد بصدق التّعاليم الدّينيّة

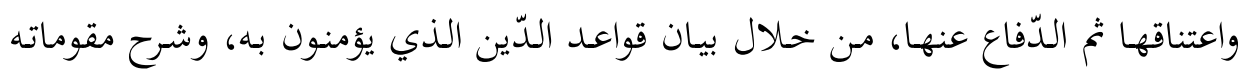

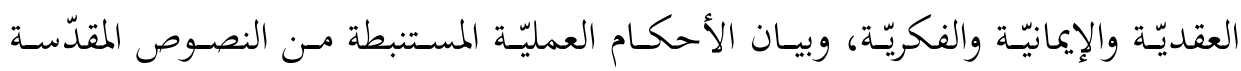

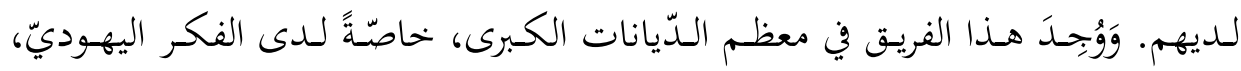
والمسيحيّ، والإسـاميّ؛ إذ قام علمـاء الكالام في هذه الدِّيانات بدراسة التعاليم الدّينية

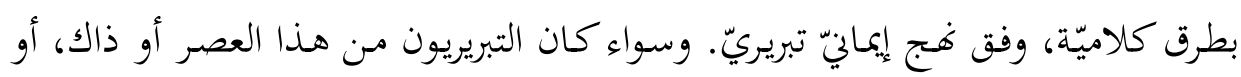
من هذا الدين أو ذاك، فإن هناك ملامح منهجيّة وموضوعيّة مشتركة في دراستهم للدين،

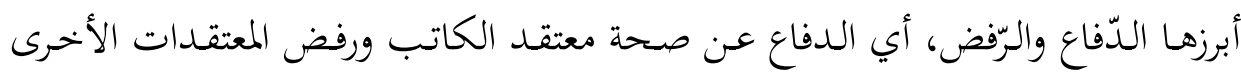

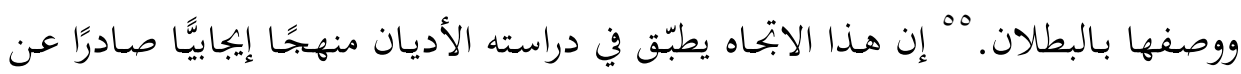

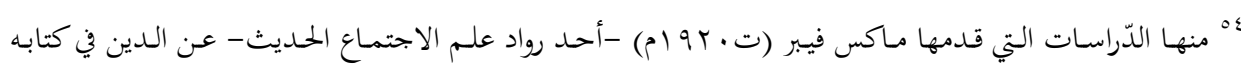

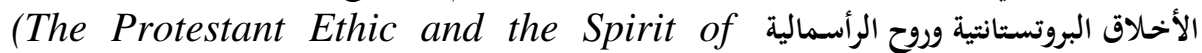
(CApitalism)

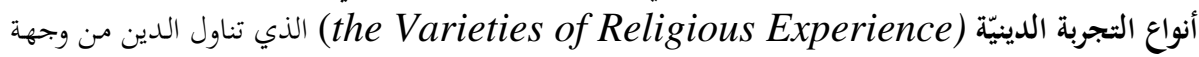

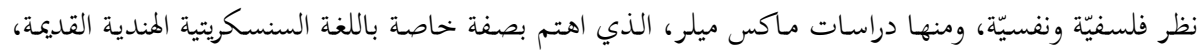
وأسهمت دراساته في الدرس المقارن للدين وعلم الأساطير. انظر :

- Weber, Max. the Protestant Ethic and the Spirit of Capitalism, Translated by Talcott Parsons, New York: Scribner, 1976.

- James. William. The Varieties of Religious Experience, New York: Image Books, 1978.

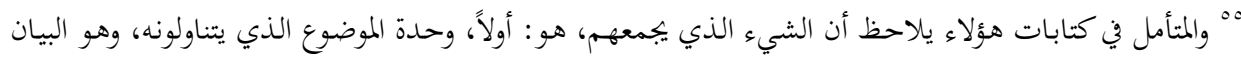

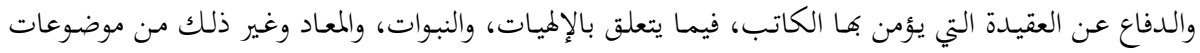


موقف إيماني، انصـرف أتباعـه إلى إثبـات العقيـة الدينيّة وأصـالتها، وبيـان مـا في النظم العقديّة مـن وححدة ونسقيّة وعقلانيّة، ومحاولة تبرير وبيـان ذلك كله بـالطرق الكلاميّة. ويتضمن تيارين؛ الأول، هو ذلك التيار الذي يميل إلى الشرح والتوضيح، وبيان العقائد، وتبسيطها من خلال النصوص الدينية المقدسة لديه. ويمكن وصف هذا التيار بأنه دراسة إنة داخليّة من أجل بيان التعاليم الدِّينّة وشرحها لمعتقديها. أما التيار الثاني، فإنه من خهلال الأدوات العقلية والنصوص النقلية يقوم الكاتب بالدفاع عن الدين الذي يعتقده وصحة مضمونه، به وذلك من خلال نفي وجود أي تناقض بين العقل ومعتقداته، ثم بيان فضيلة

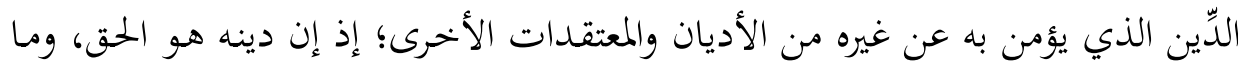

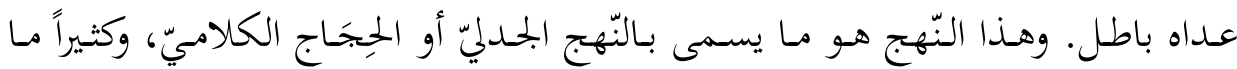
يفتقر هذا النّهج إلى الموضوعيّة العلميّة لدراسة المعتقدات.

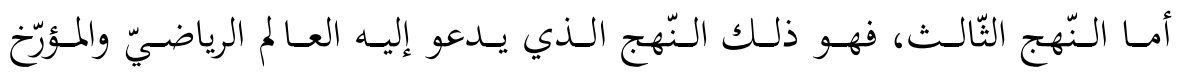

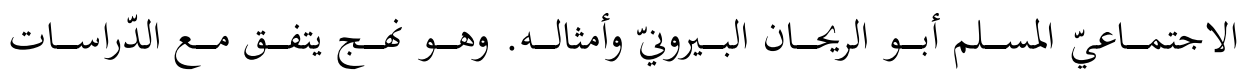

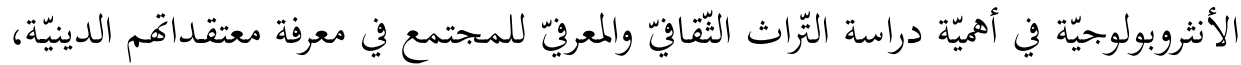
لكنه يختلف معهم في كون الدين جزءًا من الإنتاج البشريّ يخضع للسيرورة الاجتماعيّة،

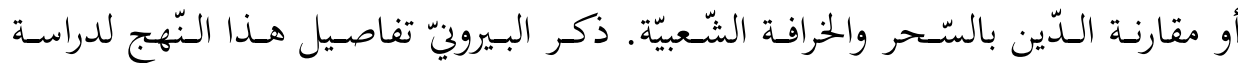

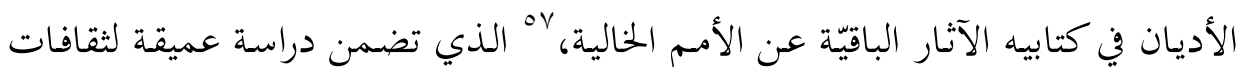
الإيمان والعقيدة. ثانياً، وحدة المنهج، بمعنى توظيف الطرق الكلامية الدفاعية، المبنية على الحجج العقلية والجدلية،

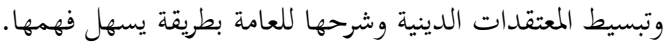

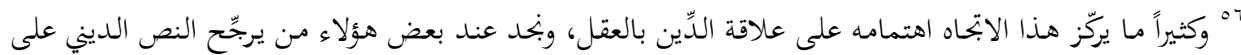

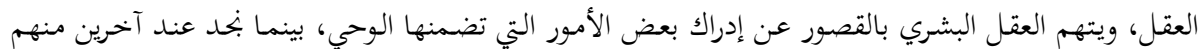

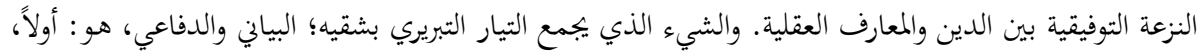

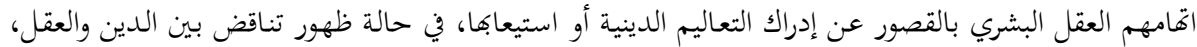

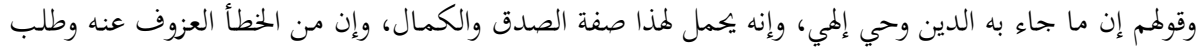

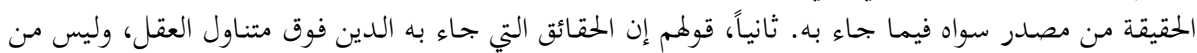

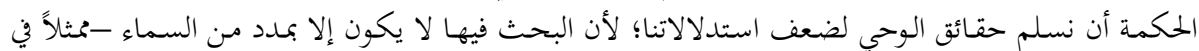

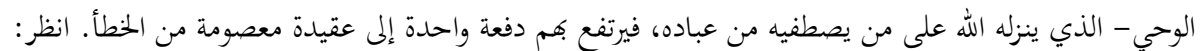

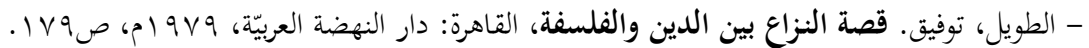

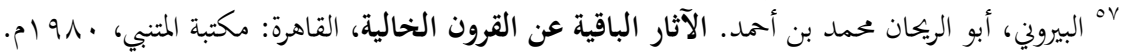


الأقوام التي سبقت الإسلام وتاريخها على نحو مقارن، وكتابه الموسوعيّ تحقيق ما للهند من مقولة مقبولة في العقل أو مرذولة، الذي تناول فيه الأديان والعادات الشيكات الشعبيّة للهند

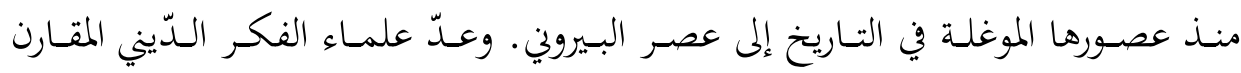

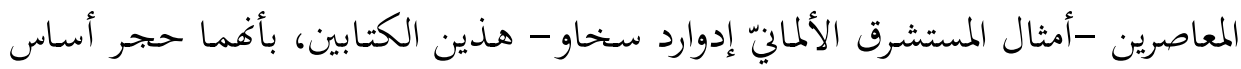
لعلم الأنثروبولوجيا الدينيّ. ومع أن البيرونيّ قدم درسه المقارن للدين بمنهج أقرب إلى المنهج الأنثروبولوجيا الدينيّ الحـديث، إلا أن منهج البيرويّ يختلف عن منـاهج الأنثروبولوجيا الدينيّة الحلديثة في عدة

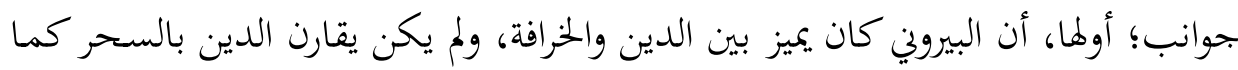
هو مشهور في الأنثروبولوجيا الدينيّة. ويشير في مقدمة كتابه عن الهند إلى ضرورة التمييز

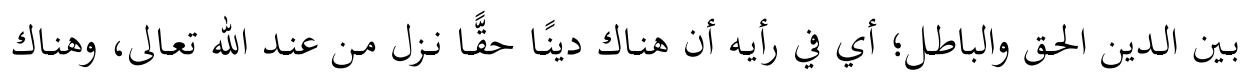
معتقدات باطلة ونحل فاسدة هي من صنع البشر، سواء عن طريق الخرافة أو الأسطورة

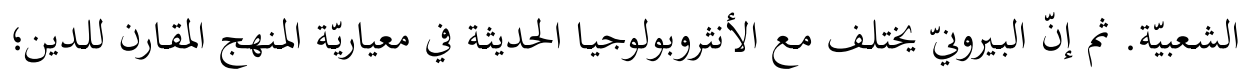

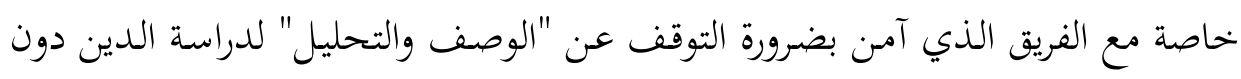

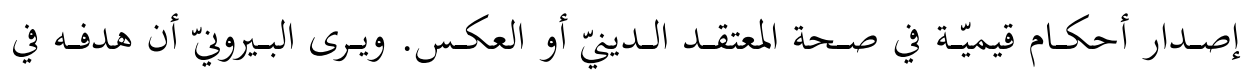

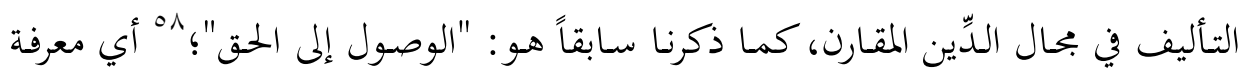
المعتقد الصحيح والسقيم مـن الدِّين، والحكـم عليها مـن حيث الصحة والبطلان، وهـو عكس ما ترمي إليه الدراسات الأنثروبولوجية الحديثة لدراسة الدين. ومسن جهة أخـرى يختلف البيرويّ مـع النهج التبريـريّ (الكلاميّ) في دراسـة الدِّين،

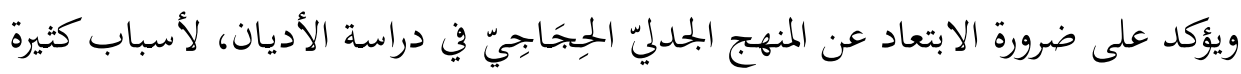

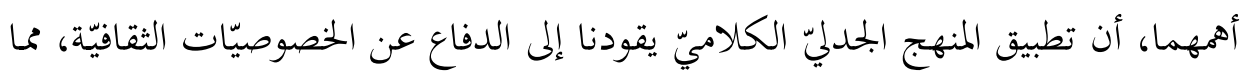

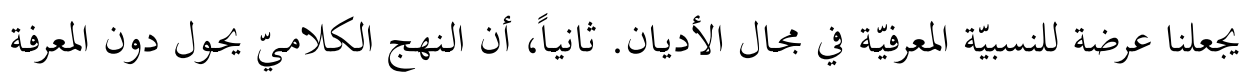
الصحيحة للأديان الأخرى، لكونه ينظر إليها من منظار تراكماته الفكريّة والعقديّة، مما لماني

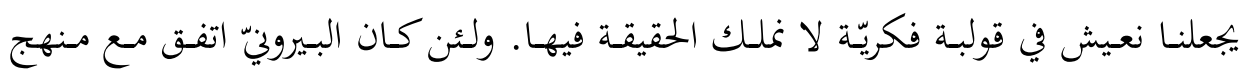
^ه البيروني، تحقيق ما للهند من مقولة مقبولة في العقل أو مرذولة، مرجع سابق، ص؟ ا. 
الأنثروبولوجيا الدِّينيّة الحديثة في أهميّة التراث الثقافيّ عند دراسة الأديان؛ إلا أنه اختلف تردي

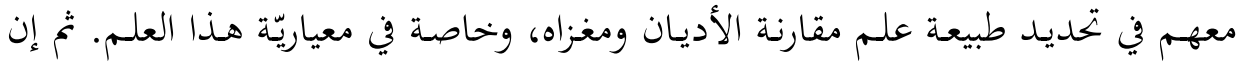
كان البيرويّّ متفقًا مع أصحاب النهج الكاميّ في ضرورة إصدار الأحكام القيميّة في

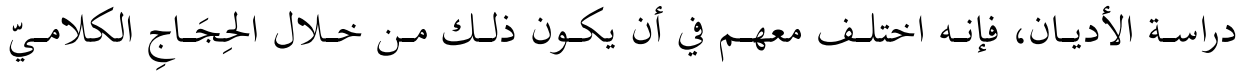

خاتمة:

إن لعلم دراسة الأديان أهميّة معرفيّة؛ إذ يساعدنا على الوقوف على حقيقة الأديان، والتعرف على مدى التشابه والتباين فيما بين الأديان. كما أن هذا العلم يساعد صاحبه إسبه

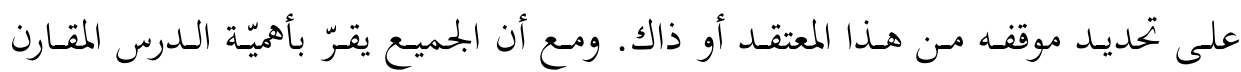

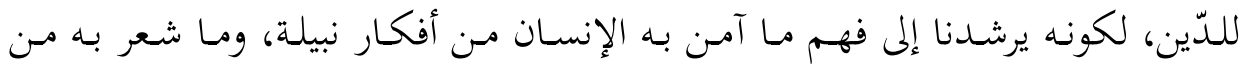

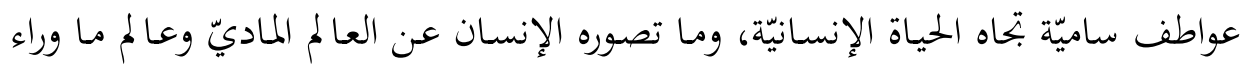

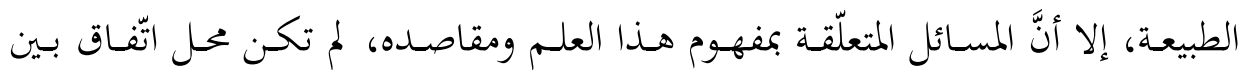

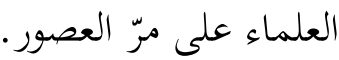

وبعد الدّراسة والتّحليل لمفهوم علم مقارنة الأديان وإمكانيّة الحصول عليه، توصل

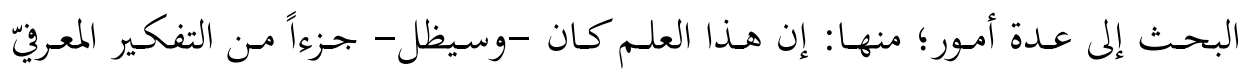

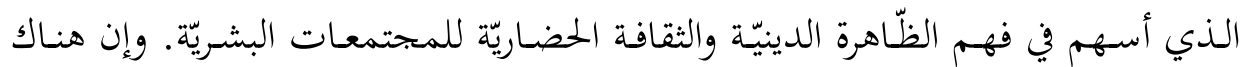

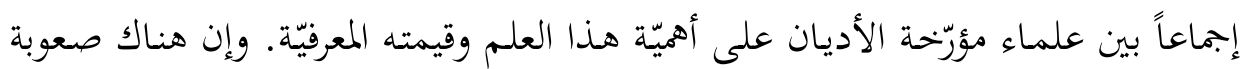

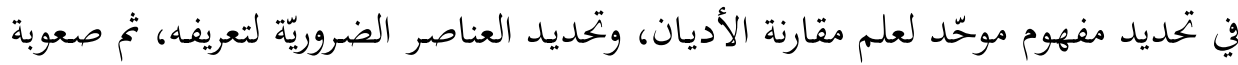

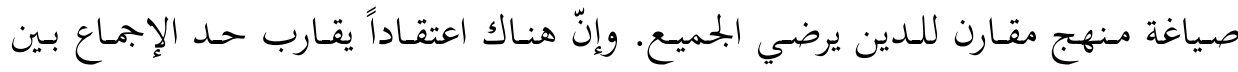

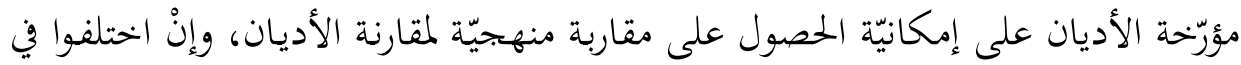
غاية تلك المقاربة وأهدافها.

وعليه فإننـا نوصي أهـل العلم والمعرفة بتجديــ علمم مقارنـة الأديـان، لكونه جهـداً

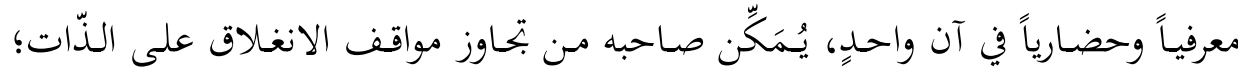


الانغلاق الذي لم يعد ممكناً في ظروف ثورة المعلومات والاتصّالات. كما ندعو إلى مزيد

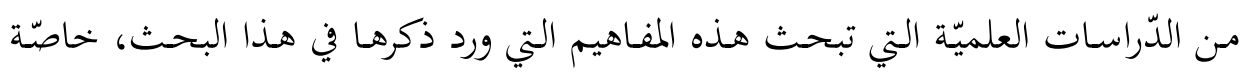
الجوانب المتعلّقة بموضوعيّة هذا العلم ومقاربات العلماء فيه، وطريقة الحصول على منهج

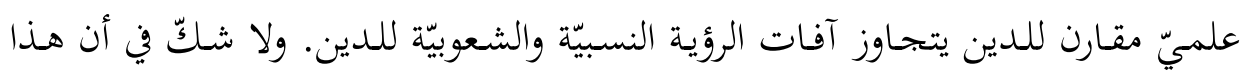
العلم أسهم في تحسين التّاهم المشترك بين أهل الأديان المختلفة، وعليه فإنـا نوصي أهل

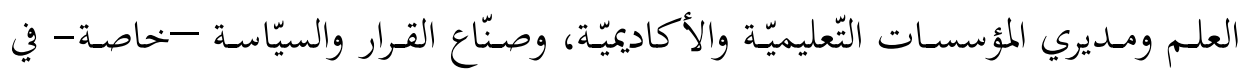

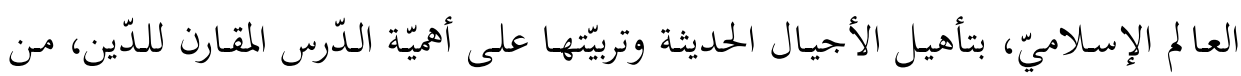

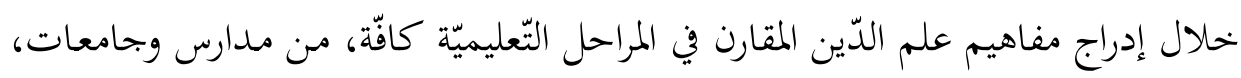
من أجل الإعداد المعرفيّ للأجيال في هذا ابلحال ذي الأهيّة الدينيّة والمعرفيّة. 